Irina Khrustaleva, Aivar Kriiska

\title{
INSIDE THE DWELLING: CLAY FIGURINES OF THE JÄGALA JÕESUU V STONE AGE SETTLEMENT SITE (ESTONIA)
}

\section{INTRODUCTION}

The Jägala Jõesuu V settlement site (further in the text Jägala) situated in the lower course of the Jägala River in northern Estonia (Fig. 1B, 9A) was discovered in 2011. It was investigated during rescue excavations under the leadership of Raido Roog and Aivar Kriiska. The remains of one pit-house with a series of different pits on the floor level, as well as a few possible fireplaces were revealed on the Stone Age site, which was covered by dune sand and tillage layers. The Stone Age cultural layer was about $15-20 \mathrm{~cm}$ thick. The settlement site is associated with the Comb Ware culture and originates from 3200-3100 years calBC (4438 \pm 29 , UBA-29062; 4460 \pm 35 , Poz-115983 and 4400 \pm 35 , Poz-115982) ${ }^{1}$ based on AMS dates. Thus, the cultural layer of the site, which was formed during a

\section{DOI: https://doi.org/10.12697/BJAH.2020.20.01}

The authors are grateful to the following: artist Jaana Ratas (Ratas \& Ratas Ltd.) and PhD Riina Rammo (Department of Archaeology of the University of Tartu) for help with photographs; PhD Maxim Charniauski (Department of Archaeology of Prehistory Society Archaeology at the Institute of History of the National Academy of Sciences of Belarus) for consultation and demonstration of the clay figurine of a bird from Kryvina peat bog; postgraduate student Maris Niinesalu (Department of Archaeology of the University of Tartu) for assistance in reviewing the Estonian Stone Age find collections; PhD Kerkko Nordqvist (Faculty of Arts of the University of Helsinki) and Phil. Licentiate Petro Pesonen (Archaeological Field Services, National Museum of Finland) for their useful comments and discussions. This study was supported by PHVAJ20919, PRG243 and Arheograator Ltd.

1 Irina Khrustaleva, Raido Roog, Margarita Kholkina, Aivar Kriiska, "Hunter-gatherer pithouses in Stone Age Estonia", Archaeological and Anthropological Sciences, 12 (56) (2020), https://doi.org/10.1007/s12520-020-01018-0 [accessed 15.02.2020]. 


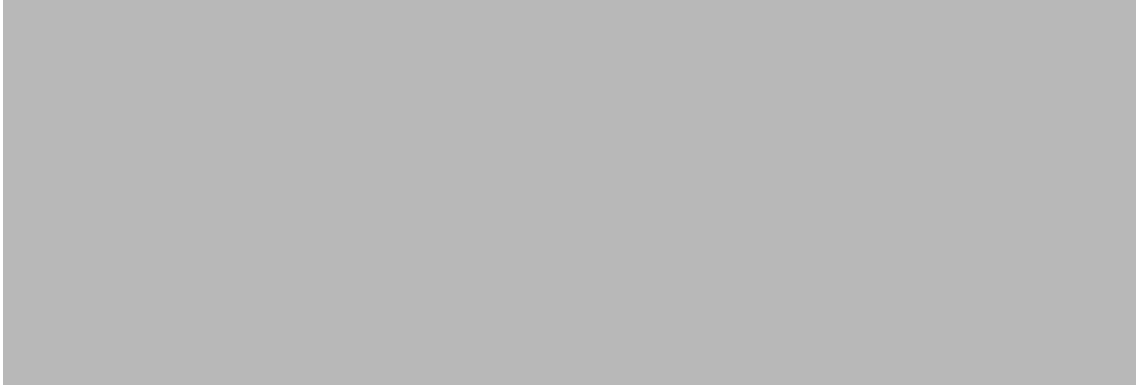

FIG. 1. (A) DISTRIBUTION OF THE STONE AGE CLAY FIGURINES IN EUROPEAN FOREST BELT: 1 AN APPROXIMATE AREA OF THE COMB WARE CULTURE (OVE HALEN, "DEN KAMKERAMISKA ARKISK ARKEOLOGI, KONTAKTSTENCIL 36 (TURKU, 1992), FIG 1. MAXIM M. CHERNYAVSKI, "KUL'TURY RANNEGO I SREDNEGO NEOLITA BELORUSSKOGO PODVIN'YA", MATERIALY, ISSLEDOVANIYA PO ARKHEOLOGII ROSSII I BELARUSI (SAINT PETERSBURG, 2012), FIG. 2; AIVAR KRIISKA, AIN MÄESALU, ANTI SELART, ET AL., EESTI AJALUGU (TALLINN, 2017) 14); 2 - AN APPROXIMATE AREA OF THE PITTED WARE CULTURE (GÖRAN BURENHULT, ARKEOLOGI NORDEN (STOCKHOLM: NATUR OCH KULTUR, 1999), FIG. 100; SANTERI VANHANEN, STEFAN GUSTAFSSON, HÅKAN RANHEDEN, NICLAS BJÖRCK, MARIANNA KEMELL, VOLKER HEYD, "MARITIME HUNTER-GATHERERS ADOPT CULTIVATION AT THE FARMING EXTREME OF NORTHERN EUROPE 5000 YEARS AGO", SCIENTIFIC REPORTS, 9 (2019), FIG. 1); 3 - AN APPROXIMATE AREA OF THE LYALOVO CULTURE SVETLANA V. OSHIBKINA, "SEVER VOSTOCHNOY EVROPY", ISKUSSTVO KAMENNOGO VEKA (LESNAYA ZONA VOSTOCHNOY EVROPY) (MOSKVA: NAUKA, 1992), 43A; NINA N. GURINA, D. A. KRAYNOV, "LYALOVSKAYA KULTURA”, ARHEOLOGIYA NEOLIT SEVERNOY EVRAZII (MOSKVA, 1996), 174-175); 4 - AN APPROXIMATE AREAS OF THE STONE AGE CLAY FIGURINES LOCATION (MARIA E. FOSS, “DREVNEYSHAYA ISTORIYA SEVERA EVROPEYSKOY CHASTI SSSR", MATERIALY I ISSLEDOVANIYA PO ARKHEOLOGII SSSR, 29 (MOSKVA, 1952); GUNBORG O. JANZON, "ZOOMORPHIC CLAY FIGURINES AND BEADS FROM IRE, HANGVAR (I) (1983): ILZE A. LOZE “ZZOBR AZHENIYA CHELOVEKA V ISKUSSTVE KAMENNOCO VEKA VOSTOCHNOY PRIBALTIKI" PERVOBYTNOE ISKUSSTVO ANTROPOMORFNIYE IZOBR AZHENIYA (NOVOSIBIRSK, 1987); ILZE A. LOZE, “NORTHERN KURZEME NEOLITHIC MINIATURE PLASTIC ART IN CLAY", AURINKONPEURA 2. SUOMEN MUINASISTAIDESURAN JULKAISUIA 2004), FIG.1; MILTON NÚNEEZ, “CLAY FIGURINES FROM THE ÅLAND ISLANDS AND MAINLAND FINLAND", FENNOSCANDIA ARCHAEOLOGICA III (1986), FIG. 1; MAXIM M. CHARNIAUSKI, "MASTATSKIYA VYRABY Z PASELISHCHAV KRYVINSKAGA TARFYANIKA", SUPOL'NASTS KAMENNAGA I BRONZAVAGA VYAKOV MIZHRECHCHA VISLY I DNYAPRA: ZBORNIK NAVUKOVYKH ARTYKULAV PAMYATSI MIHALA CHARNYAVSKAGA (MINSK, 2015), FIG. 11, ETC.) (B) STONE AGE SITES WITH CLAY FIGURINES IN ESTONIA AND INGRIA: 1 - JAGALA JỐESUU V, 2 - NAAKAMAE, 3 - SINDI-LODJA III, 4 - VALMA, 5 - TAMULA I, 6 - VILLA I, 7 - KÄÄPA, 8 AKALI, 9 - RIIGIKÜLA II, 10 - LOMMI III.

relatively short period and buried under the dune sand, is a closed settlement complex that has no analogy in Estonia. The finds, which total about 11,500, formed two concentrations on the excavated area of the site. The first concentration was situated on the eastern part of the site and is connected to the filling of a pit-house, while the second in the western part of the site could not be connected to any noticeable features.

The collection was based mainly on quartz and bone finds and potsherds, as well as flint, stone and amber artefacts. Burnt hazelnut shells were also found there. Of the 97 fragments of burnt clay not identified as potsherds, 91 were determined to be fragments of clay figurines, while the rest were just pieces of burnt clay. These figurine fragments, which are the objects of our research, have now turned out to be the most abundant deposit of clay figurines and their fragments in the eastern Baltic.

The purpose of this paper is to describe and classify the sculpted clay figurines from Jägala, to analyse the features of their location at the site, and, if possible, to reconstruct images of the found figurines, interpret them and, since almost all were broken, try to determine if they were broken intentionally. The focus is on more or less identifiable specimens. It is especially important that the material from the Jägala settlement allows the location of the figurine fragments to be analysed, because the context of such finds on sites is often unclear for a number of reasons, such as the preservation of the cultural layer, techniques of excavation and documentation, etc.

One of the objectives of the study is to bring figurines found at Jägala into the general context of the Stone Age clay sculptures in the European forest belt, which have mainly been associated with Comb and Pitted Ware cultures sites (Fig. 1A). In this regard, the cataloguing of the Stone Age clay figurines of Estonia and Ingria was carried out by authors. Not only were previously known and published materials collected, but some old archaeological finds from Comb Ware culture settlement sites available during the research process were also reviewed in the archaeological collections of the Department of Archaeology, University of Tartu (finds with the markings TÜ), Archaeological Research Collection, Tallinn University (finds with the markings AI) and Pärnu Museum (PäMu). New figurines and their fragments were identified at six sites: Sindi-Lodja III, Riigiküla II, Villa I, Kääpa, Lommi III and Tamula I (Fig. 1B; Appendix 1). Several radiocarbon dates from the sites with clay figurine fragments are being published for the first time.

\section{METHODS}

In order to describe the fragments of clay figurines, they were divided into groups based on visually detectable admixtures (probably natural in most cases, but no separate study of this issue was conducted) in the clay moulding mass, the features of the surface treatment and the ornamentation, when this could be determined. To check the 
intentional fragmentation of the figurines, a visual inspection was carried out primarily using a magnifying glass, and more specifically, a Nikon SMZ1000 microscope under magnification from 8 to 20 times. Experimental research took place as well. Seven burnt clay samples represented by plates sized from $40 \times 40 \mathrm{~mm}$ to $50 \times 50 \mathrm{~mm}$ and a thickness of ca $7 \mathrm{~mm}$ were fired at temperatures between $700-1000^{\circ} \mathrm{C}$ and then broken, using two different striking techniques, with (1) a soft (elk antler) and (2) a hard (flint lump) hammer. Three types of breakage were tested using both hammers by (1) striking the edge or (2) centre while the object was being held in the hand and (3) striking the centre on a wood anvil. Each clay sample was struck once using a specific technique. The resulting pieces and impact marks were documented and compared with the fragments of archaeological figurines.

The accuracy of the field documentation during the excavation of the Jägala settlement site allowed us to use spatial analysis. Handdrawn find distribution plans were manually digitised. Spatial analysis was conducted using AutoCAD 2013 Autodesk Software and Surfer 11 Golden Software. The locations of all the fragments of clay figurines on the area of the site were identified and their positions relative to the pit-house, as well as each other, established.

In order to compare the clay figurines from Jägala with similar finds from other Stone Age sites in Estonia and neighbouring territories (primarily, Finland, Karelia and Latvia), the external characteristics (size, ornamentation, image interpretation, etc.) of the identified figurines were analysed, as were some features of their positions at the archaeological sites

The radiocarbon dates of the Estonian sites with clay figurines were obtained from burnt and unburnt animal bones, the food crust on the Comb Ware potsherds, burnt hazelnut shells, charcoal, wood and peat. Samples were dated by the acceleration mass spectrometry (AMS) technique at the Kiel Leibniz-Laboratory for Radiometric Dating and Isotope Research (KIA), the Poznań Radiocarbon Laboratory (Poz) and the Laboratory of Chronology, Finnish Natural History Museum (Hela), and by conventional technique at Radiocarbon Laboratory of University of Tartu (TA). The dating results have been calibrated using the OxCal v4.3.2, and the IntCal13 atmospheric curves. ${ }^{2}$

2 Christopher Bronk Ramsey, "Bayesian analysis of radiocarbon dates", Radiocarbon, 51 (1) (2009), 337-360; Christopher Bronk Ramsey, OxCal 4.3 manual (2017), https://c14.arch.ox.ac. ak/oxcal/OxCal.html [accessed 15.02.2020], Paula J. Reimer, Edouard Bard, Alex Bayliss, et al., "Intcal13 and marine13 radiocarbon age calibration curves $0-50,000$ years calBP", Radiocarbon, 55 (4) (2013), 1869-1887.

\section{CLASSIFICATION OF THE FRAGMENTS} OF CLAY FIGURINES FROM JÄGALA JÕESUU V

Eleven different qualitative and quantitative groups of items were distinguished among the 91 finds that were determined to be fragments of clay figurines. Most of them are unidentified due to their small size. The maximum size of the fragments is $30 \mathrm{~mm}$ and most (69 pcs) does not weigh more than 1 gram. Therefore, some of them might be fragments of daub, or just burnt clay, but this cannot definitely be established.

Group 1. One whole item (TÜ 1972: 1000) is oval in shape with pointed ends with a small longitudinal protruding rib on one side and a slightly smoothed surface on the opposite somewhat flattened side (Fig. 2: 1). The figurine is $35.6 \mathrm{~mm}$ long with a maximum diameter of approximately $14 \mathrm{~mm}$. The clay moulding mass has an admixture of sand. One end of the figurine has two rounded pits made with a thin stick. The item is brown in colour and reddish in some places. The surface is loose and covered with cracks. The figurine was found among the concentration of finds in the western part of the excavation area (Figs. 9 \& 10B).

The figurine seems to be zoomorphic. The longitudinal protruding rib clearly resembles a dorsal fin, while the flattened opposite side (belly) without any fins makes it impossible to assume that this is an image of a fish, although it could be a marine animal. The only cetacean that occurs and breeds regularly in the Baltic Sea with a similar body structure is the harbour porpoise (Phocoena phocoena), although the clay figurine does not have a pronounced tail ${ }^{3}$. The harbour porpoise is characterised by a small dorsal fin and a short nose that transitions smoothly to the head. Despite the figurine having a slightly different shaped 'nose', it could only be identified as a harbour porpoise (Fig. 2: 2). Images of Phocoenidae are rather rare in the Stone Age and only occur in the rock art of Norway. ${ }^{4}$ As far as the image style is concerned, one could mention, for example, the bronze coins in the form of dolphins from Olbia (an ancient Greek

3 Juhan Aul, Harri Ling, Kalju Paaver, Eesti NSV imetajad (Tallinn: Eesti Riiklik Kirjastus, 1957), 274

4 Jan Magne Gjerde, "Marine Mammals in the Rock Art of Alta, Norway, Northernmost Europe", Wahle on the Rock II. Korean Prehistoric Art II (Ulsan: Ulsan Petroglyph Museum, 2018), 201 


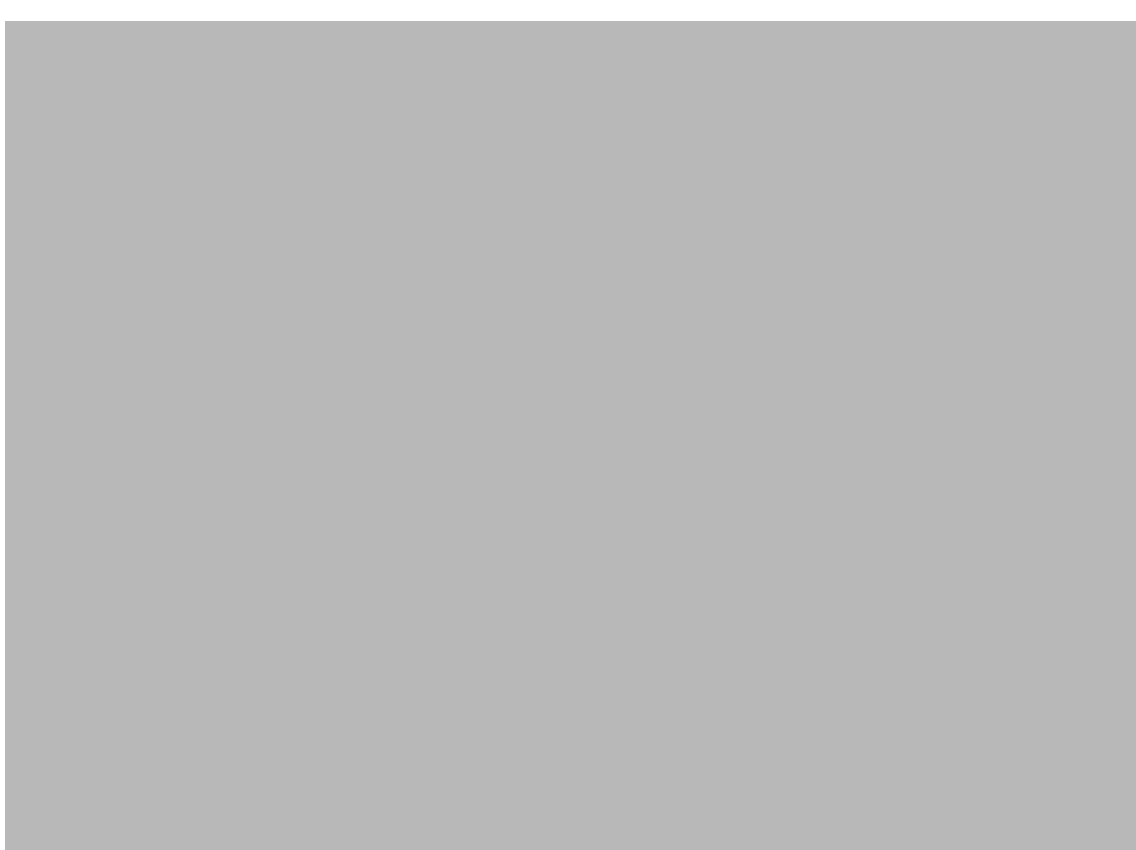

FIG. 2. GROUP 1: 1 - CLAY FIGURINE (TÜ 1972: 1000); 2 - AN INTERPRETATION OF THE FIGURINE IMAGE. PHOTOS: IRINA KHRUSTALEVA; AN IMAGE OF A HARBOUR PORPOISE: AUL, LING, PAAVER, EESTI NSV IMETAJAD, ATT. VIII: 3.

colony on the coast of the Black Sea). These coins are often stylised so that only the animal's body with a pronounced dorsal fin - the main recognisable feature - is represented. ${ }^{5}$

Group 2. The fragment (TÜ 1972: 2498) of a semi-cylindrical item that is $20 \mathrm{~mm}$ long with a diameter of $14.2 \mathrm{~mm}$ has a 'groove' filled with the remains of a parched substance passing through its centre along the long axis (Fig. 3). The figurine is made of clay without any visible admixtures. It has a smooth surface that is reddish in colour with several deep cracks. It was found in the pit-house at the floor level (Figs. 9 \& 10A). This is probably a fragment of the body or legs

5 Petr O. Karyshkovskiy, Monetnoe delo i denezhnoe obrashchenie Olvii (VI v. do n.e. - IV v n.e.) (Odessa: A.S. Fridman; 2003), Tab. II-VI; Nina A. Frolova, Michail G. Abramzon, Monet Olvii v sobranii Gosudarstvennogo Istoricheskogo muzeya. Katalog (Moskva: ROSSPEN, 2005), Tab. 1-6.

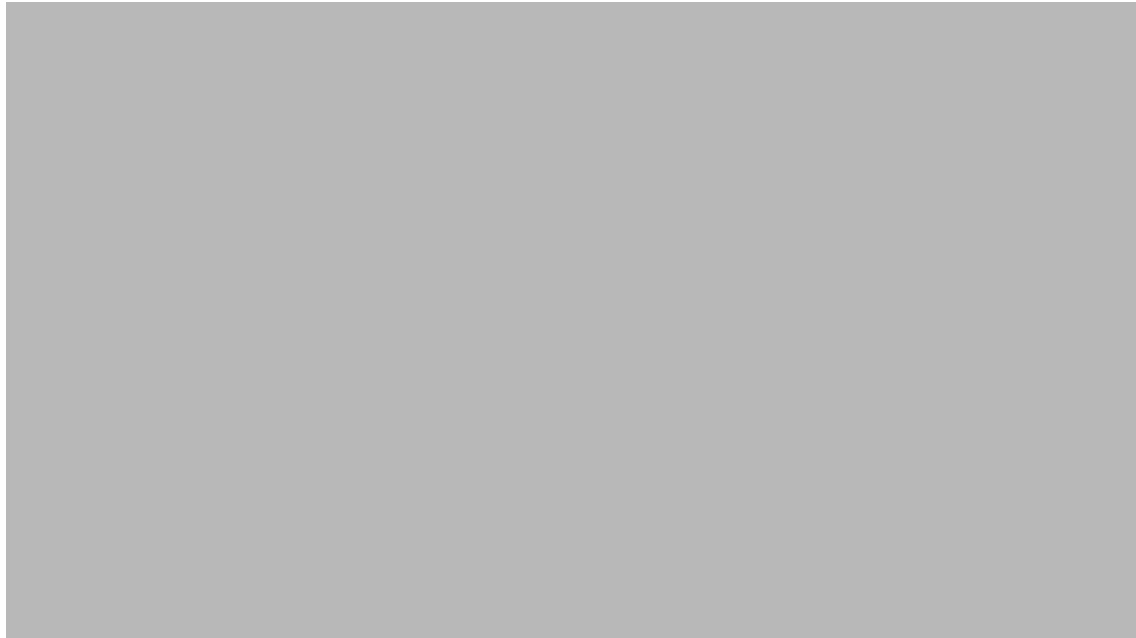

FIG. 3. GROUP 2: FRAGMENT OF (ANTHROPOMORPHIC?) CLAY FIGURINE (TÜ 1972: 2498). PHOTOS: IRINA KHRUSTALEVA.

of an anthropomorphic figurine, which has analogies among Finnish clay sculptures ${ }^{6}$ (Figs. 25 and 31).

Group 3. Five fragments (TÜ 1972: 2170, 2400, 2479, 2504, 2526) with a small amount of fine sand having been added to the clay moulding mass are decorated with deep (up to $2.3 \mathrm{~mm}$ ) pits of irregular round or sub-rectangular shapes, and are from 0.2 to $1.3 \mathrm{~mm}$ in diameter (Fig. $4: 1-5$ ). The pits were made using a stick with an irregular (ragged) end, and therefore, longitude linear traces are visible in some places on the surface. It is not possible to determine the ornamental motif: in some places the pits are arranged in rows, in others, they form concentrations and almost overlap each other. Two fragments, with a thickness of approximately $9.3 \mathrm{~mm}$, were parts from the edges of the figurines. They are dense, brown-coloured with a smooth surface and without cracks. All the fragments were found in the pit-house filling (Figs. 9 \& 10A). Based on the fragments, it seems that the figurine was flat with ornamentation on one side (and the edges) and smooth on the other. 6 E.g. Aarne Äyräpää, “Kampakeraamisen kulttuurin savikuviot”, Suomen Museo, 48 (1941) 


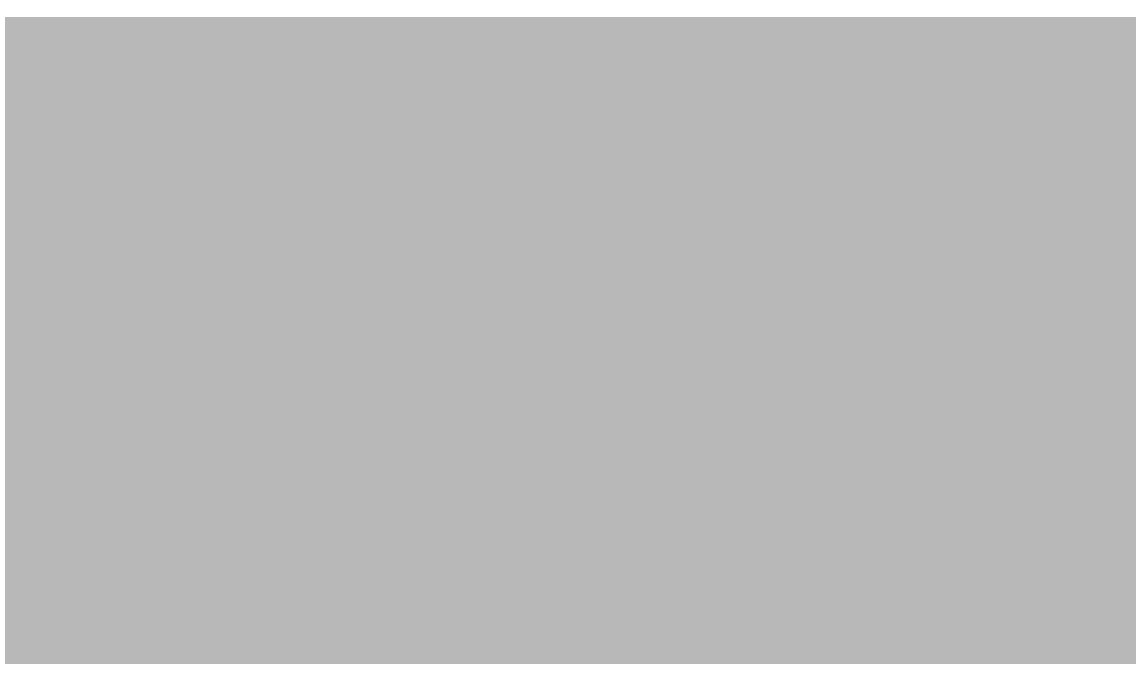

FIG. 4. GROUP 3: FRAGMENTS OF (ANTHROPOMORPHIC?) CLAY FIGURINE (1 - TÜ 1972: 2400; 2 TÜ 1972: 2479; 3 - TÜ 1972: 2526; 4 - TÜ 1972: 2504; 5 - TÜ 1972: 2120). PHOTOS: IRINA KHRUSTALEVA.

Similar finds have been discovered in Latvia, at the Nainiekste Comb Ware culture settlement site in the Lubāna lowland', as well as at the Pitted Ware culture Grävingsområde II and Jettböle sites in the Finnish Åland Islands 8 (Fig. 10; Fig. 5), where scalps of figurines of whole anthropomorphic creatures, or just anthropomorphic heads, were depicted in this manner. An ornithomorphic figurine decorated with pits was found at the Krivina 3 settlement site in northern Belarus $^{9}$ (Fig. 11). Since the pits are quite deep, bird feathers or

7 Ilze Loze, Akmens laikmeta māksla Austrumbaltijā (Rīga: Zinatne, 1983), Att. 76; Ilze Loze, "Izobrazheniya cheloveka v iskusstve kamennogo veka Vostochnoy Pribaltiki", Pervobytnoe iskusstvo. Antropomorfniye izobrazheniya, ed. by R. S. Vasilevskiy (Novosibirsk: Nauka 1987), 41-42

8 Carl Frederik Meinander, "Kolsvidja", Studia neolithica in honorem Aarne Äyräpää. Suomen Muinaismuistoyhdistyksen Aikakauskirja 58 (Helsinki, 1957), 185-219; Milton G. Núñez, "Clay figurines from the Åland islands and mainland Finland", Fennoscandia Archaeologica III (1986), 17-34.

9 Maxim M. Charniauski, "Mastatskiya vyraby z paselishchav Kryvinskaga tarfyanika", Supol'nastsi kamennaga i bronzavaga vyakov mizhrechcha Visly i Dnyapra: Zbornik navukovykh artykulav pamyatsi Mihala Charnyavskaga, ed. by V. U. Asheychyk, M. A. Plavinski, V. M.
Sidarovich (Minsk, 2015).

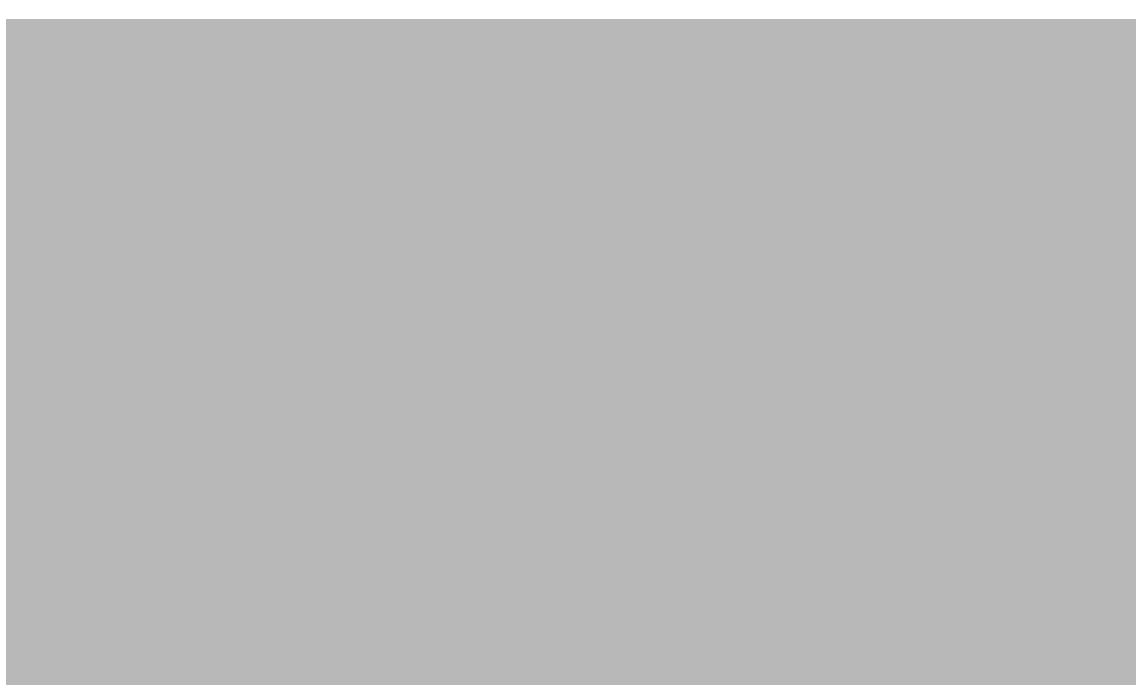

FIG. 5. GROUP 4: FRAGMENTS OF CLAY FIGURINES (1 - TÜ 1972: 2487; 2 - TÜ 1972: 1643). PHOTOS: RINA KHRUSTALEVA.

something similar could have been inserted into them..$^{10}$ Therefore, these finds from Jägala have been interpreted as fragments (of the head?) of an anthropomorphic figurine.

Group 4. Two fragments with a small amount of sand admixture in clay. One has a slightly smoothed side (TÜ 1972: 1643; Fig. 5: 2); the other (TÜ 1972: 2489; Fig. 5: 1) has an imprint of a long and round object (stick) on its broken end. The stick was at least $3.2 \mathrm{~mm}$ in diameter and $13 \mathrm{~mm}$ long. It is impossible to determine if it was the detail of a figurine or just burned-out organic material from the clay moulding mass. The fragments are dense, of a brown and reddish colour and without any visible pores or cracks on the surface. The first fragment was found in the western part of the excavation to the southeast of the main concentration of finds, the second one was in the filling of the pit included in the pit-house construction (Figs. 9

10 Aleksandr M. Zhulnikov, Eneolit Karelii (pamyatniki s poristoy i asbestovoy keramikoy) (Petrozavodsk: Rossijskaja Akad. Nauk, Karel'skij Naučnyj Centr, Inst. Jazyka, Literatury Istorii, 1999), 71 


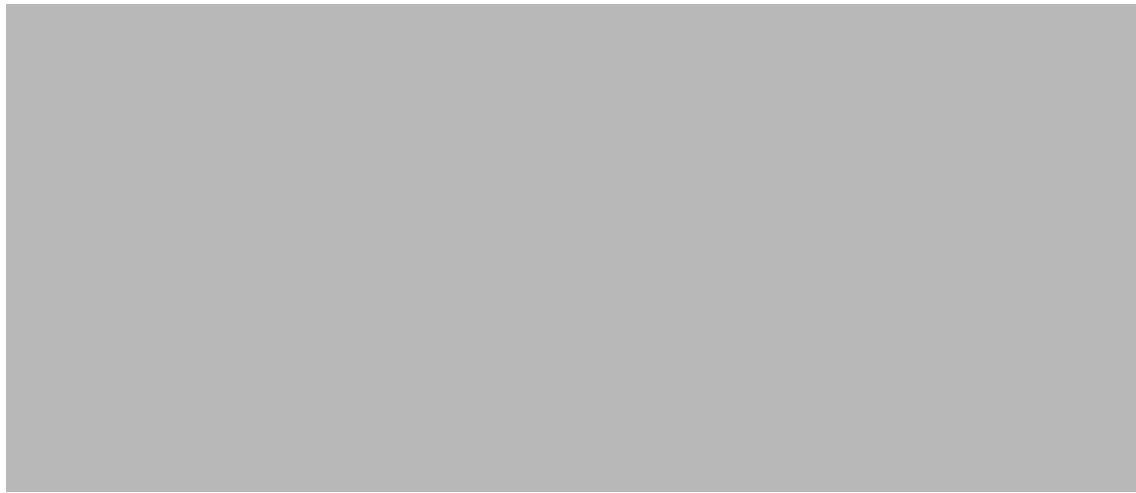

FIG. 6. GROUP 5: FRAGMENTS OF CLAY FIGURINES (1 - TÜ 1972: 1473; 2 - TÜ 1972: 1693; 3 - TU 1972: 2412; 4 - TÜ 1972: 1350; 5 - TÜ 1972: 2476; 6 - TÜ 1972: 695; 7 - TÜ 1972: 3952; 8 - TÜ 1972: 2153). PHOTOS: IRINA KHRUSTALEVA, AIVAR KRIISKA

\& 10A, B). These fragments can be connected to the figurine from group 3 or they could be details of one or a few of the other figurines

Group 5. Thirty-one fragments with an admixture of fine and medium-grained sand. Seven of these have hematite (or similar) temper that was visible on the surface. The fragments are mainly small and undefinable; some have pinches made by fingers, imprints of which are visible on the burnt clay (Fig. 6). Two fragments are from edges of the figurines (TÜ 1972: 1473, 2153), one is decorated with pits on one side (Fig. 6: 1, 8). One rounded fragment (TÜ 1972: 1693) that is $15.6 \times 11 \mathrm{~mm}$ in size has thin notches along all of its edge (Fig. 6: 2). This is the only object that was located far from all the concentrations of finds in the southeast part of the excavation (Fig. 9). Some other fragments have the same kind of notch, but they are not as clear. All the fragments have a brown surface colour. Some could probably be connected to the figurine from group 3 , but it is difficult to determine this precisely. Fragments of this group are present in almost equal proportions in both concentrations of finds at the settlement site with slightly more of them being found in the pit-house (Figs. 9 \& 10A, B).

Group 6. Seventeen fragments have an admixture of mediumand coarse-grained sand and organic material in the clay moulding mass. Most of them are represented by amorphous pieces, some

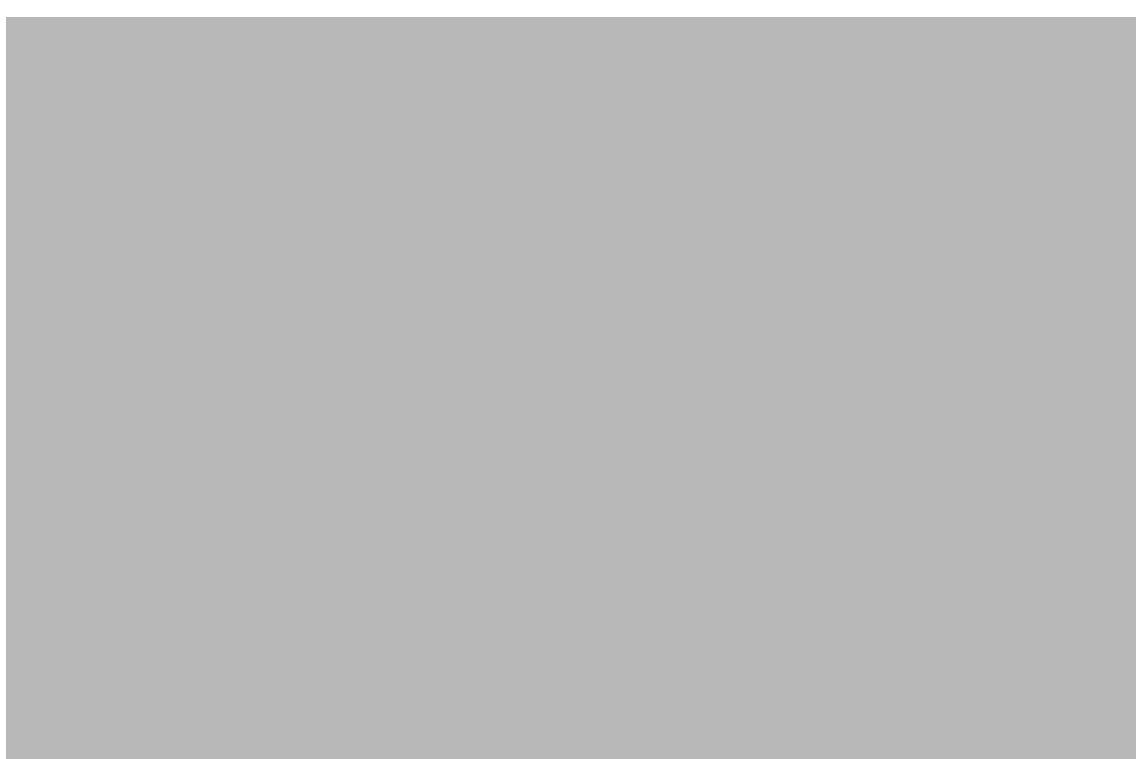

FIG. 7. GROUP 6: FRAGMENTS OF CLAY FIGURINES (1 - TÜ 1972: 2559; 2 - TÜ 1972: 2409; 3 - TU 1972: 1424; 4 - TÜ 1972: 1447). PHOTOS: IRINA KHRUSTALEVA.

with sculpting or linear traces (Fig. 7). One piece (TÜ 1972: 1447) has unclear remains of small pits or notches on the surface (Fig. 7: 4). Most of the fragments (8) were situated in the filling of the pithouse; five others were in the concentration from the western part of the excavation; and another four were mainly located in the mixed layer outside the main excavated area (Figs. 9 \& 10A, B).

Group 7. Five amorphous fragments (TÜ 1972: 2499) of brown colour with an admixture of coarse-grained sand and rock debris added to the clay were found in the filling of the pit-house (Figs. 9 \& 10A).

Group 8. This group is represented by five fragments (TÜ 1972: 1631) probably from one unidentified item of brown colour with a smoothed surface. The clay moulding mass has an admixture of stones up to $6.5 \mathrm{~mm}$ in size. One piece, which is the pointed end of a figurine, is $11 \times 12 \times 7 \mathrm{~mm}$ in size (Fig. 8: 1). These fragments were found in the mixed layer outside the main excavated area (Fig. 9).

Group 9. This group consists of five fragments of figurines (TÜ 1972: 2421) which are grey in colour, and made of clay with 


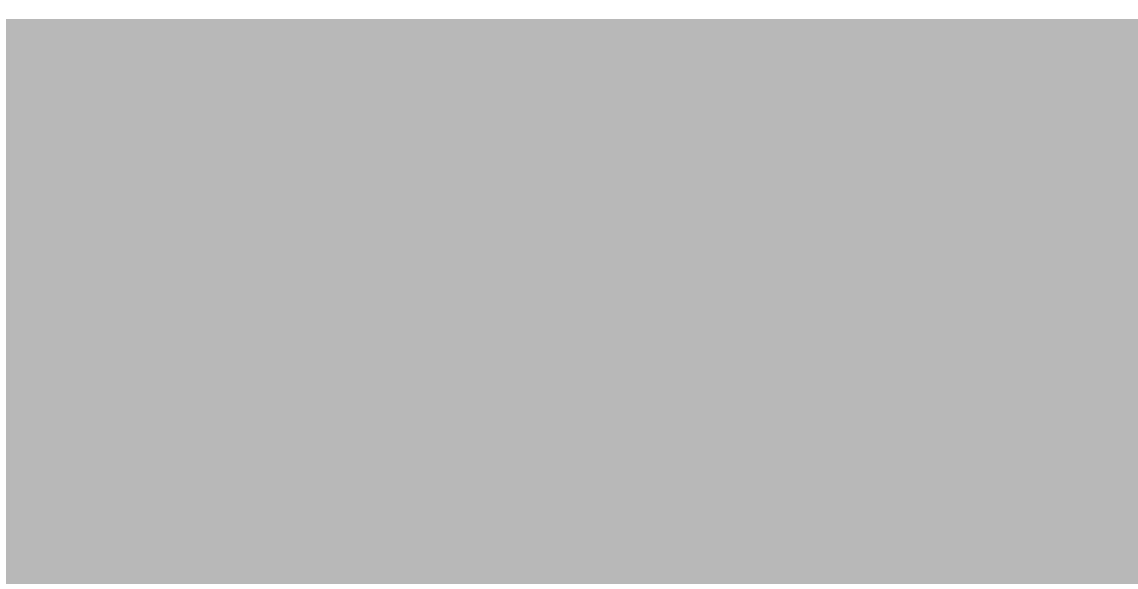

FIG. 8. FRAGMENTS OF CLAY FIGURINES: 1 - GROUP 8, 2 - GROUP 9, 3 - GROUP 10 (1 - TÜ 1972 1631; 2 - TÜ 1972: 2421; 3 - TÜ 1972: 2291). PHOTOS: IRINA KHRUSTALEVA.

an admixture of sand and mineral 'flakes' (their nature was not determined). One side of all the fragments were decorated with deep crossed lines and notches, while the other side was smooth having however visible linear traces (Fig. 8: 2). All the fragments were flat with a thickness of $6-8 \mathrm{~mm}$. They were located on the floor level of the pit-house (Figs. 9 \& 10A).

It is impossible to determine what items these fragments belonged to, but there are some common features with the ornamented figurines and their fragments from the Comb Ware culture sites Gipka ${ }^{11}$ and Pūrciems ${ }^{12}$ in Latvia, from some sites in Finland (e.g. Toispuolannummi and Jettböle $)^{13}$ and from the east coast of the

11 Ilze Loze, Neolīta apmetnes Ziemelkurzemes kāpās (Rīga: Latvijas vēstures institūta apgāds, 2006), Att. 22

12 Ibidem, Att. 36.

13 Núñez, "Clay figurines from the Åland islands and mainland Finland".
Onega Lake in Russia ${ }^{14}$. Most of these figurines are associated with anthropomorphic images. ${ }^{15}$

Group 10. Two small fragments (TÜ 1972: 2490, 2291) have an admixture of shells, which were not completely burnt. One fragment (TÜ 1972: 2291) that is $9.5 \times 10.8 \mathrm{~mm}$ in size was decorated with deep crossed lines (Fig. 8: 3). Both fragments were located in the filling of the pit-house, but at different levels (Figs. $9 \& 10 \mathrm{~A}$ ).

Group 11. The remaining seventeen unidentified fragments of clay figurines are included in the last group. Three pieces (TÜ 1972: $959,2208,771)$ were represented by flat fragments with linear traces (decoration?) on one side. Fragments from this group were found both in the filling of the pit-house and in the concentration from the western part of the excavation (Figs. 9 \& 10A, B).

\section{SPATIAL ANALYSIS OF THE CLAY FIGURINES FROM JÄGALA JÕESUU V}

The spatial analysis of the clay figurines from Jägala shows that $57 \%$ of fragments (52 pcs) were located in the northeast part of the excavated area and associated only with the filling of the pit-house and pits on its floor (Fig. 9B). All the presumed fragments of anthropomorphic figurines (groups 2 and 3) were also found here in different parts of the pit. Almost all the rest of the fragments, i.e. $42 \%$, most of which were unidentified (groups 5, 6 and 11), as well the presumed figurine of a harbour porpoise, were located in the western part of the excavated area and associated with the concentration of other finds. This accumulation of archaeological material can indicate the remains of some settlement structure in this area the traces of which have not survived. Just a few fragments of figurines were located in the mixed layer outside of these two main concentrations. Their relation to any features of the site cannot be determined.

The vertical projection of the western part of the excavation (Fig. $10 \mathrm{~B}, \mathrm{C})$ shows that all the fragments were found in a thin line of the cultural layer, and the presumed figurine of the harbour porpoise

14 Svetlana V. Oshibkina, Neolit Vostochnogo Prionezhya (Moskva: Nauka, 1978), 102-103. 15 Svetlana V. Studzitskaya, "Izobrazhenie cheloveka v melkoy plastike neoliticheskih plemen lesnoy zona Evropeyskoy chasti SSSR", Novie materialy po istorii plemen Vostochnoy Evrop vepohu kamnya i bronzy. Trudy Gosudarstvennogo ordena Lenina istoricheskogo muzeya 60,
ed. by N. Ya. Merpert (Moskva, 1985), 100-118. 


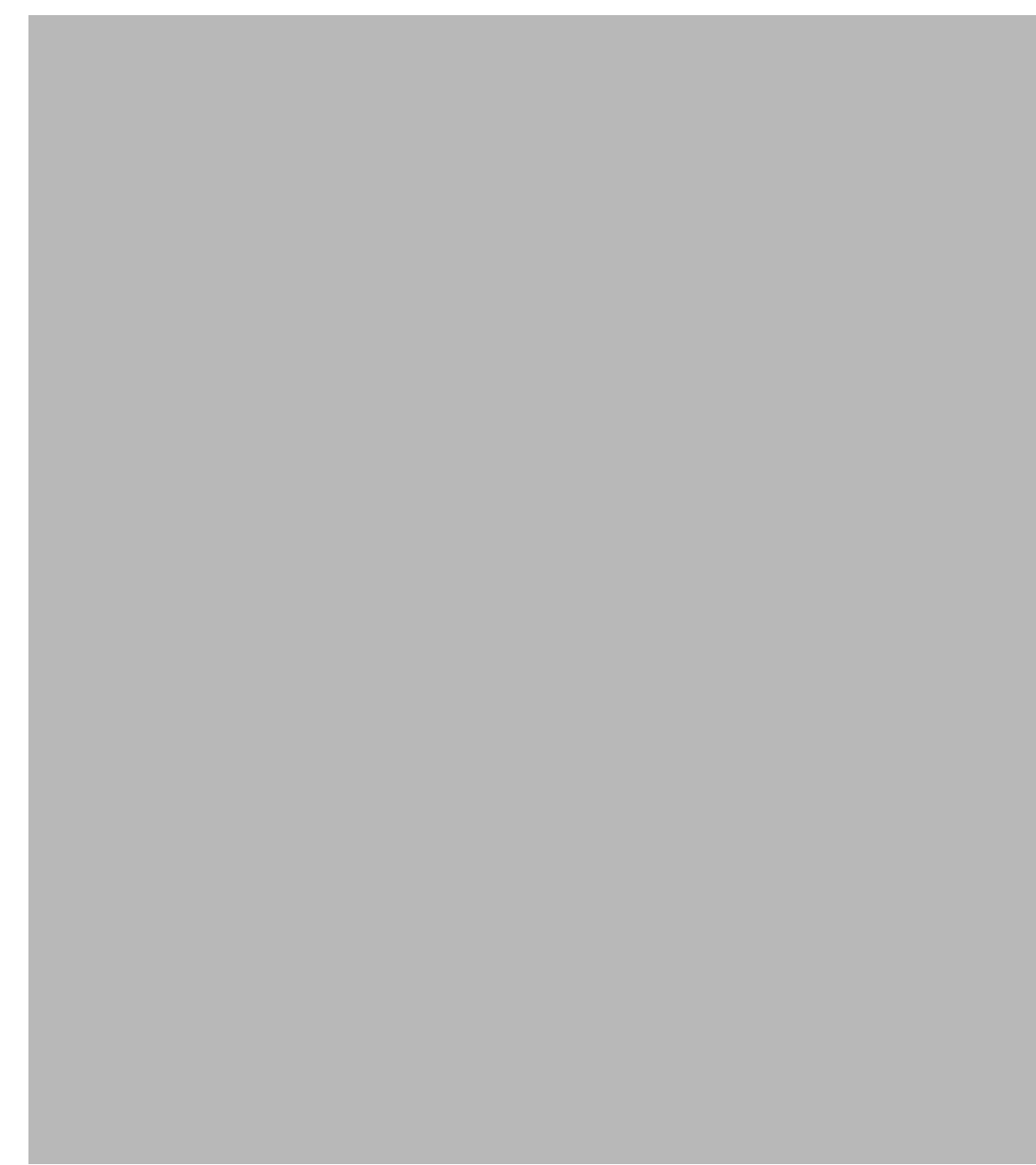

FIG. 9. J̈̈GALA JÕESUU V SETTLEMENT SITE. (A) MAP SHOWING THE DETAILED LOCATION OF THE SITE. (B) POSITION OF GROUPS OF CLAY FIGURINES ON THE EXCAVATED AREA OF THE SITE: 1 - GROUP 1, 2 - GROUP 2, 3 - GROUP 3, 4 - GROUP 4, 5 - GROUP 5, 6 - GROUP 6, 7 - GROUP 7, 8 - GROUP 8, 9 - GROUP 9, 10 - GROUP 10, 11 - GROUP 11, 12 - FRAGMENTS OF BURNT CLAY, 13 - PITS ON THE BASE LAYER, 14 - OUTLINE OF THE PIT-HOUSE SPOT REVEALED IN THE UPPER LAYER (FROM RAIDO ROOG, AIVAR KRIISKA, ARUANNE ARHEOLOOGILISTEST PÄÄSTEKAEVAMISTEST JÄGALA JÕESUU V ASULAKOHAL JA FOSSIILSETEL POOLLUJAANUSTEL JUUNIS JA JUULIS 2011 (2019). MANUSCRIPT IN THE ARCHIVE OF ARCHAEOLOGY AT UNIVERSITY OF TARTU; BASE MAP. ESTONIAN LAND BOARD; MODIFIED BY IRINA KHRUSTALEVA).

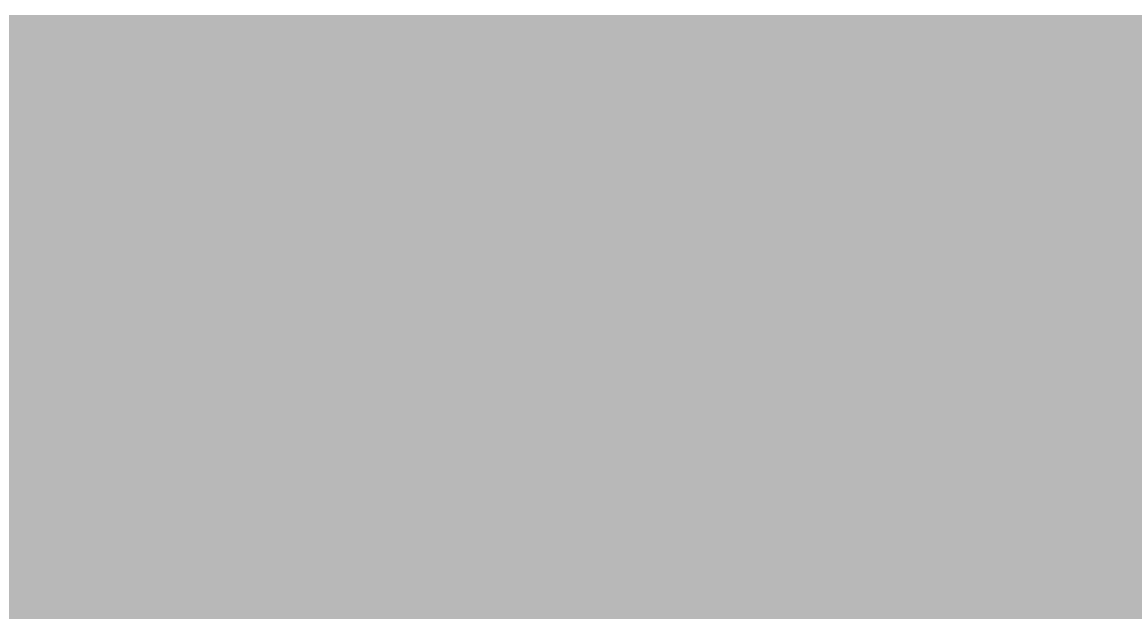

FIG. 10. VERTICAL PROJECTION OF THE POSITION OF GROUPS OF THE CLAY FIGURINES ON THE JÄGALA JÕESUU V SETTLEMENT SITE (FOR SYMBOLS SEE FIC 9). (A) STR ATIGRAPHY OF THE EASTERN PART. (B) STRATIGRAPHY OF THE WESTERN PART. (C) SCHEME OF THE EXCAVATED AREA WITH THE LOCATION OF THE STRATIGRAPHIC SECTION (FROM ROOG, KRIISKA, ARUANNE ARHEOLOOGILISTEST PÄÄSTEKAEVAMISTEST JÄGALA JÕESUU V ASULAKOHAL JA FOSSIILSETEL PÕLLUJÄÄNUSTEL JUUNIS JA JUULIS 2011; MODIFIED BY IRINA KHRUSTALEVA).

was located on the bottom. In the pit-house the main concentration of sculptured fragments was located in the middle level of the filling, but some fragments were found at the bottom of the pit (Fig. 10A, C). Fragments from group 3 (presumed details of an anthropomorphic figurine) were revealed on different levels of the pit filling. There is no correlation between the size of the fragments and the level of their deposition.

The picture of the spatial position of clay figurines in the eastern part clearly shows their connection to the filling of the pit-house, not its association with the bottom pits. Their distribution throughout the entire pit volume (especially the fragments from group 3) indicates continuity in the use of the pit-house. The western part of the excavation site probably indicates some more or less short-term episode that took place at that location. 


\section{THE STONE AGE CLAY FIGURINES FROM ESTONIA AND ADJOINING TERRITORIES}

Estonia's and Ingria's earliest clay crafts belong to the Narva culture (ca 5200-3900 years calBC). ${ }^{16}$ They are generally represented by round rods with pointed ends, less often by small balls or lumps of clay. A large number of such items were found at the Riigiküla (Fig. 11) and Narva Joaorg settlement sites in northeastern Estonia, as well as on other Narva culture sites in Estonia, for example at Sindi-Lodja III in the southwest, at Kääpa in the southeast, and at Akali in east of the country. ${ }^{17}$ However real clay figurines appeared only on the Comb Ware culture sites (ca 3900-1800 years calBC) ${ }^{18}$ that existed in Estonia after the Narva culture.

Until now only 13 clay figurines from Estonia and Ingria have been reported in archaeological literature, found on five sites: Valma, Tamula I, Akali, Naakamäe and Lommi III (Fig. 1B). ${ }^{19}$ The first figurine was discovered in 1940 at the Lommi III settlement site ${ }^{20}$ during excavations led by Richard Indreko, who, among other things, researched Stone Age figurines made of different materials in Estonia ${ }^{21}$. However most of the published figurines were collected in the 1950s and 1960s during

16 For the dates of the cultural phases see: Aivar Kriiska, Ain Mäesalu, Anti Selart, Inna Poltsam-Júro, Pârel Pinrinae, Marten Seppel, Andres Andresen, Ago Pajur, Tõnu Tannberg, Eesti ajalugu (Tallinn: Avita, 2017).

17 Nina N. Gurina, "Iz istorii drevnikh plemen zapadnikh oblastey SSSR (po materialam Narvskoy expeditsii)", Materiali i issledovaniya po arkheologii SSSR, 144 (Leningrad, 1967), 107; Aivar Kriiska, "Narva joe alamjooksu ala neoliitiline keraamika", Eesti arheoloogia Akadeemia Kirjastus, 1995), 74-75; Aivar Kriiska, Marilin Rappu, "Riigiküla II a sulakoh 2006.-2007. aasta arheoloogiliste päästekaevamiste tulemused”, Maal, linnas ja linnuses. Narva Muuseumi toimetised 8, ed. by Aivar Kriiska, Merike Ivask, Katrin Martsik (Narva: Narva Muuseum, 2008), 22.

18 E.g. Lembit J. Jaanits, Poseleniya epohi neolita i rannego metalla v priust'e $r$. Emayig 18 E.g. Lembit J. Jaanits, Poseleniya epohi neolita i rannego metalla v priust'e r. Emayigi
(Estonskaya SSR) (Tallinn: Akademia Nauk ESSR, 1959), 273; Aivar Kriiska, Andres Tvauri, Eesti muinasaeg (Tallinn: Avita, 2002), 74-75.

19 Jaanits, Poseleniya epohi neolita i rannego metalla v priust'e $r$. Emayigi (Estonskaya SSR), 273-276; Tõnno Jonuks, Eesti muinasusund (Tartu: Tartu Ülikooli Kirjastus, 2009), 109

20 Richard Indreko, "Bemerkungen über die wichtigsten steinzeitlichen Funde in Estland in den Jahren 1937-1943", Antikvariska Studier III. Kungl. Vitterhets Historie och Antikvitet akademiens handlingar 65 (Stockholm, 1948), 299.

21 See: Kristiina Johanson, Tõnno Jonuks, Aivar Kriiska, Mari Tõrv, "From the first people to idols and figurines. Richard Indrcko as a scientist", Man, his time, artefacts, and places. University of Tartu, Institute of History and Archaeology, 2013), 95-179.

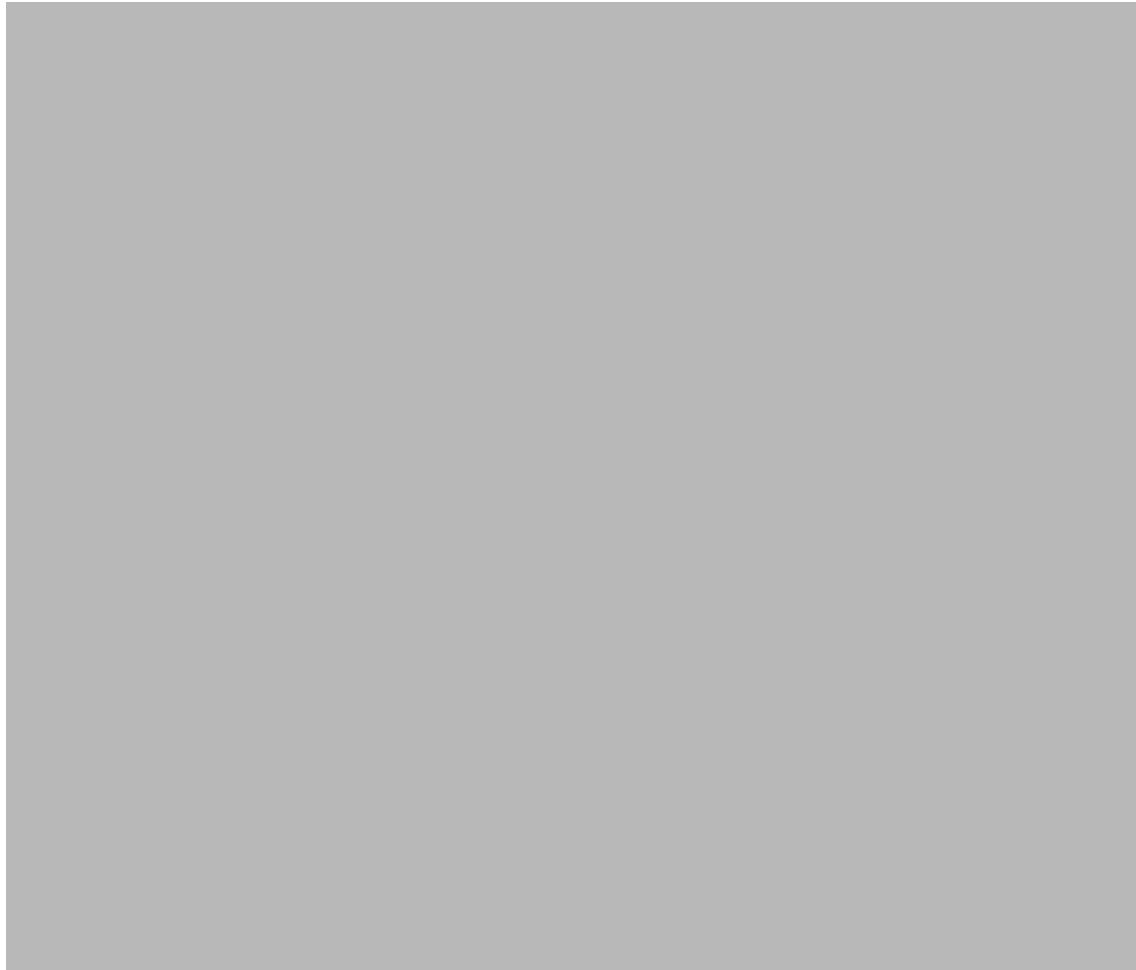

FIG. 11. CLAY ITEMS OF THE NARVA CULTURE FROM THE RIIGIKÜLA I SETTLEMENT SITE (THE FINDS ARE STORED IN THE PETER THE GREAT MUSEUM OF ANTHROPOLOGY AND (THE FODS ARE (KUNSTKAMERA) IN RUSSIA). PHOTO: AIVAR KRIISKA.

excavations led by Lembit Jaanits..$^{22}$ Basically, all of the clay figurines were fragmented and were not always recognised among other finds, which prompted us to check the currently available archaeological collections of other Comb Ware culture sites from Estonia and Ingria including those which were already represented by figurines. Thereby, 21 new instances were added to the catalogue. Eight figurines and their fragments were found in the collection of the Sindi-Lodja III, two in the Riigiküla II, one in the Villa I and one in the Kääpa settlement site find material (Fig. 1B; Appendix 1). Some new figurine fragments were

22 Lembit J. Jaanits, "Novye dannye po neolitu Pribaltiki", Sovetskaya arkheologiya, 19 (1954), 195-196; Jaanits, Poseleniya epohi neolita i rannego metalla v priust'e r. Emayigi (Estonskay
SSR), 273-277; Jonuks, Eesti muinasusund, 109. 
also discovered in the find collection of the Lommi III ( 3 pcs) and the Tamula I (6 pcs) settlement sites. The main task was not to collect all of the Stone Age clay figurines from Estonia, but this review of some collections showed a great possibility for the future research of this topic

Our revision of the 34 instances of Stone Age clay figurines discovered in Estonia (including a new approach to previously published items) revealed two whole (Fig. 12: 1, 3) and eleven fragments, most of which included the lower parts of anthropo- or anthropo-zoomorphic figurines (e.g. Fig. 12: 2, 4), three zoomorphic figurines (Fig. 12: 6,7), as well as one ornitho- (Fig. 12: 5) and one ornitho- or anthropomorphic (Fig. 12: 8) figurine. Apart from the figurines, five lumps (four with pits) and eleven unidentified fragments were found. One whole anthropo-zoomorphic figurine from Valma was covered with ochre (Appendix 1: 1) and four fragments with ornamentation: from Akali, Lommi III and SindiLodja III (two of lower parts of anthropo- or anthropo-zoomorphic figurines, one zoomorphic and one unidentified figurine) (Appendix 1: 3, 17, 20,30). This last decorated fragment (Appendix 1: 30) from the Sindi-Lodja III site is similar to the fragment from group 6 found in Jägala (Fig. 7: 4). Ornamentation on the anthropomorphic figurine fragment from Akali perhaps indicates clothes, as have, for example, some Paimio and Åland instances in Finland ${ }^{23}$ (Fig. 6). Among the figurines only the items from Riigiküla II can clearly be linked to the feature of the settlement site. They were found in the fireplace, and have a radiocarbon date of ca 3650 years calBC (Appendix 1: 32-33).

The Comb Ware cultures (Typical Comb Ware, Late Comb Ware, Pöljä Ware and Kierikki Ware), existed in the interval ca 3900-1800 years calBC ${ }^{24}$, are also represented by the abundance of figurines in Finland, Karelia and Latvia (Fig. 1). ${ }^{25}$ In Finland, some figurines

23 Äyräpää, "Kampakeraamisen kulttuurin savikuviot", 86; Núñez, "Clay figurines from the Åland islands and mainland Finland".

24 For the dating of the cultural phases see: Kriiska, Mäesalu, Selart, et al., Eesti ajalugu, 15 Kerkko Nordqvist, Tapani Rostedt, Aivar Kriiska, "Kivikauden maailma (

25 E.g. Aarne Europaeus, "Uusia kivikauden taidelöytöjä", Suomen Museo, 36 (1929), 87 Ayräpää, "Kampakeraamisen kulttuurin savikuviot"; Núñez, "Clay figurines from the Alan islands and mainland Finland", 20; Petro Pesonen, "Zoomorphic clay figurines from two Stone Age sites in Raakyla, North Karelia", De temporibus antiquissimis ad honorem Lembit Jaanits, ed. by Valter Lang, Aivar Kriistka (Tallinn: Teaduste Akadeemia Kirjastus, 2000), 181-191; Ilze Loze, "Northern Kurzeme Neolithic miniature plastic art in clay", Aurnkonpeura 2 (Tartu. Eest Muinastaideselts, Suoinen muinaistaileserra, 2004), 67-85, 1ga Zagorska, Sectets of Ancien Lake Burtnieks. Stone Age Sites by the Shore of Lake Burtnieks (Riga: Zinātne, 2017), 81, Fig. 59.

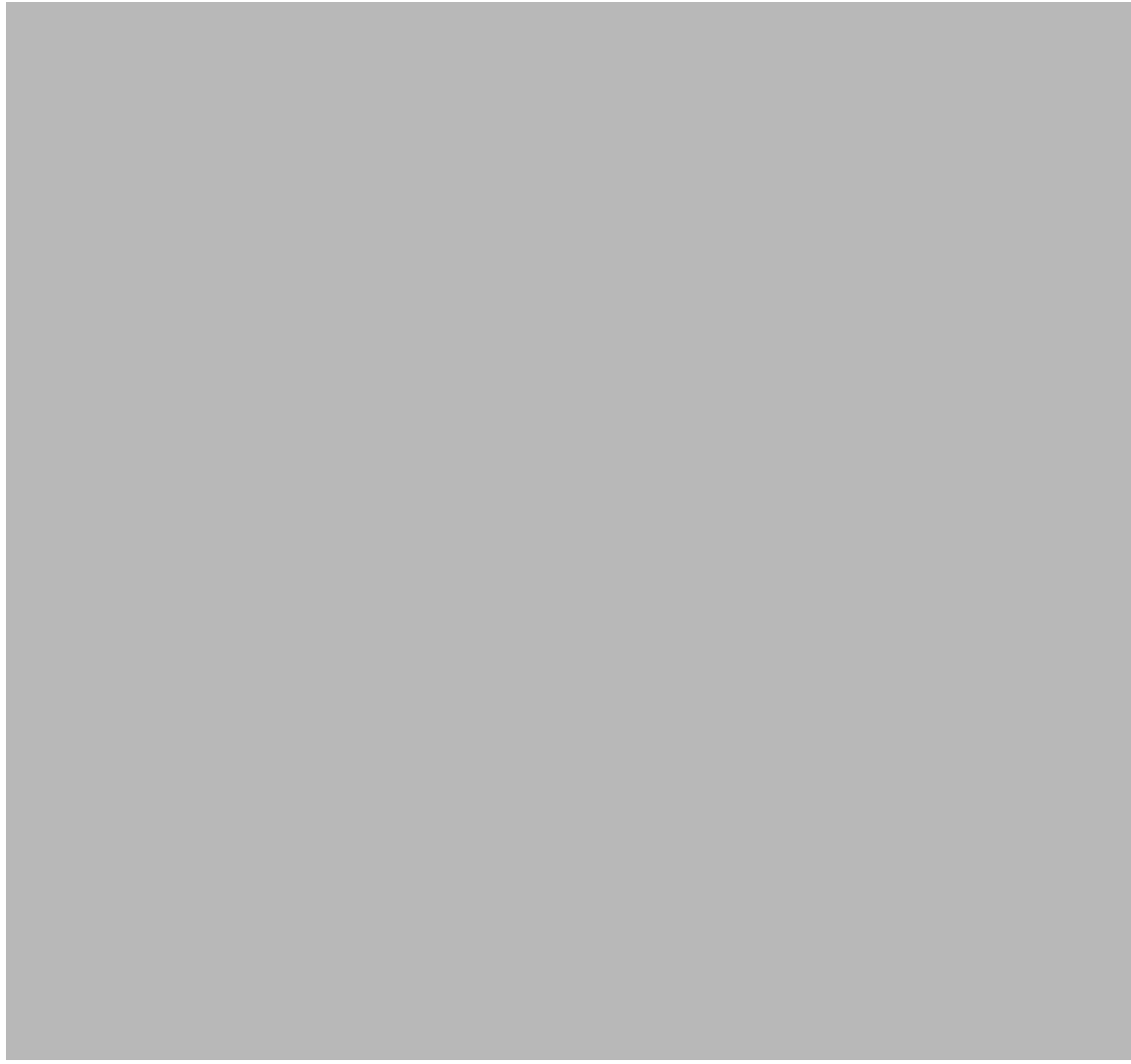

FIG. 12. STONE AGE CLAY FIGURINES FROM ESTONIA AND INGRIA: 1 - VALMA (APPENDIX 1: 1); 2 - AKALI (APPENDIX 1: 2); 3 - VILLA I (APPENDIX 1: 34); 4 - AKALI (APPENDIX 1: 3); 5 17): 8 - LOMMI UI (APPENDIX 1: 19). PHOTOS. JAANA RATAS.

have also been found in the context of the Sperrings culture (also known as the Early Comb Ware culture ${ }^{26}$, that ranged from ca 5150 to 4200 years calBC ${ }^{27}$. However, they also occurred outside the Comb Ware culture, including in the Pitted Ware culture (3500-2300

26 Europaeus, "Uusia kivikauden taidelöytöjä", 86-87; Torsten Edgren, "Kivikausi", Suomen historia l, ed by Yriö Blomstedt (Espoo: Weilin-Göös, 1982), 59; Núñez "Clay figurines from the Åland islands and mainland Finland", 19.

27 Petro Pesonen, Markku Oinonen, Christian Carpelan, Päivi Onkamo, "Early Subneolithic Ceramic Sequences in Eastern Fennoscandia - A Bayesian Approach", Radiocarbon, 54 (3-4) (2012), 661. 
years calBC $)^{28}$ in Sweden and Finland's Åland Islands ${ }^{29}$ and the PitComb Ware cultures (primarily the Lyalovo culture) in western and northwestern Russia ${ }^{30}$, as well as on the area of the Funnel Beaker culture (4100-2800 years calBC) ${ }^{31}$, in Denmark ${ }^{32}$.

All the figurines in the forest belt of Europe were made according to the general principle of using one piece of moulding clay mass with different admixtures. Small figurines (the size did not exceed $10 \mathrm{~cm}$ ) were fired at different temperatures and their surfaces are often porous and covered with cracks ${ }^{33}$.

Small balls, discs, fragments of rings and bars, as well as diverse lumps of clay are present in the collections of finds ${ }^{34}$, for example, similar clay lumps with pits were found at Kääpa, Lommi III and Sindi-Lodja III (Appendix 1: 15, 21, 23 \& 31). However, the images represented among the figurines are mainly anthropomorphic, zoomorphic and ornithomorphic. The anthropomorphic sculptures (which prevail) are spread over a smaller area than the ornithomorphic figurines: anthropomorphs are not found south of northern Latvia, while individual finds of ornithomorphic objects are have been found in northern part of Lithuania and Belarus (Fig. 1: A).

28 For the dating of the cultural phases see: Santeri Vanhanen, Stefan Gustafsson, Håkan Ranheden Niclas Björck, Marianna Kemell, Volker Heyd, "Maritime Hunter-Gatherers Adopt Cultivation

29 Matts Dreijer, "Ålands äldsta bebyggelse", Finskt museum, 47 (1940), 51-53; Meinander "Kolsvidja", 200-201; Gunborg O. Janzon, "Zoomorphic clay figurines and beads from Ire, Hangvar parish, Gotland", Tidskrift för svensk antikvarisk forskning, 78 (I) (1983), 1-20 Núnez, "Clay figurines from the Åland islands and mainland Finland"; Bozena Werbart, "D mänsklinga kontakterna i Östersjöområdet”, Arkeologii i Norden, 1 (Stockholm, 1999), 338-339. 30 Maria E. Foss, "Stojanka Kubenino", Sovetskaya arkheologiya, 5 (1940), 51; Maria E. o arkheologii SSSR, 29 (Moskva, 1952); Maĭi a P. Zimina, Neolit basseyna r. Msty (Moskva: zd-vo "Nauka", 1981); E. L. Kostyleva, A. V. Utkin, Proizvedeniya izobrazitel'nogo iskusstva VI-III tis. do n.e. iz sobraniya arheologicheskogo muzeya IvGU. Katalog (Ivanovo, 2007), 10.

31 For the dating of the cultural phases see: Martin Hinz, Ingo Feeser, Karl-Göran Sjögren, Johannes Müller, "Demography and the intensity of cultural activities: an evaluation of Funne 32 Jørgen Skaarup, Stengade. Ein langeländischer Wohnplatz mit Hausresten aus der frühneolithischen Zeit (Rudkøbing: Langelands Museum, 1975).

33 Ekaterina A. Kashina, "Nabory lepnykh zoomorphnykh skulptur v neolite-eneolite lesnoy zony Vostochnoy Evropy i Finliandii", Mif obrjad i ritualnij predmet v drevnosti, ed by S.A. Arutyunov (Yekaterinburg, Surgut: Magellan, 2007), 125.

34 Vesa-Pekka Herva, Teemu Mökkönen, Kerkko Nordqvist, "A northern Neolithic? Clay work, cultivation and cultural transformations in the Boreal zone of North-Eastern Europe, c. 5300-3000 BC", Oxford Journal of Archaeology, 36 (1) (2017), 28.
The predominant type of anthropomorphic figurine has specific traits, which is the reason they are called 'bent idols ${ }^{\prime 35}$ or 'embryonic' ${ }^{36}$ in the literature. They are curved with the back arched so that the head and legs are extended forward, sometimes quite significantly. The details of the body and face are poorly developed so that the legs and arms are often not separated from the body (although there are a few specimens with separated legs); a large pointed nose and overhanging forehead strongly protrudes forward, and the eyes can be indicated by pits. Some figurines have pitted, notched, pointed or 'comb' decoration, and for some, a visible back crest made by pinching is characteristic. ${ }^{37}$ The same type of figurine was discovered at the Valma, Akali, Tamula I and Villa I sites in Estonia and Lommi III in Ingria. Although the images are different, each of them has some features that could be considered 'bent' (Fig. 13: 1-4). The figurine from Valma is a rare example of a two-legged image with outlined arms and a crest on its back. It does not have any direct analogies, although some two-legged figurines are known in Finland and Karelia ${ }^{38}$. A strongly curved figurine from Villa I without any visible features of a body or face has numerous analogies in Finland (Fig. 1, 5: a, 6: f) ${ }^{39}$. Compared to other anthropomorphic figurines, represented by standing figurines or just heads, 'bent' sculptures are more likely to be intact, although there are also fragmented examples ${ }^{40}$. Most of the fragments of presumed anthropomorphic

35 E.g. Timo Miettinen, "En idol från Hietaniemi i Luopioinen”, Finskt Museum, 81 (1964), 39; Edgren, "Kivikausi", 59

36 E.g. Svetlana V. Oshibkina, "Sever Vostochnoy Evropy", Iskusstvo kamennogo veka (Lesnaya zona Vostochnoy Evropy), ed. by T. M. Potemkina (Moskva: Nauka, 1992), 53; Indre R. Antanaitis, "Interpreting the Meaning of East Baltic Neolithic Symbols", Cambridge Archaeological Journal, 8 (1) (1998), 58; Adomas Butrimas, "Human figurines in Eastern-Baltic Prehistric Art", Prehistoric Art in the Baltic Region, ed. by Adomas Butrimas (Vilnius: Vilnius Academy of Fine Arts, 2000), 22 -23; Jonuks, Eesti muinasusund, 109.

37 Miettinen, "En idol från Hietaniemi i Luopioinen", 35; Studzitskaya, "Izobrazhenie cheloveka v melkoy plastike neoliticheskih plemen lesnoy zona Evropeyskoy chasti SSSR", 102; Adomas $\mathrm{v}$ melkoy plastike neoliticheskih plemen lesnoy zona Evropeyskoy
Butrimas, "Human figurines in Eastern-Baltic Prehistric Art", 22.

38 Petro Pesonen, "Archaeology of the Jaamankangas area - with special reference to the Rääkkylä Porrinmöki Stone Age settlement site", Environmental Studies in Eastern Finland. Reports of the Ancient Lake Saimaa Project. Helsinki Papers in Archaeology 8 (Helsinki, 1996), Fig. 4

39 Miettinen, "En idol från Hietaniemi i Luopioinen", Fig. 3.

40 Anatoly P. Zhuravlev, "Skul'ptury i nekotorye drugie glinyaniye izdeliya iz eneoliticheskogo poseleniya Vigaynavolok", Arkheologicheskiye issledovaniya v Karelit, ed. by I. Pankrushe Leningrad: Nauka, 1972), 91-92; Núñez, "Clay figurines from the Åland islands and mainlan Finland", 26. 
figurines from Jägala probably were not the 'bent' type, but rather were standing figurines or just heads (in group 3).

Many of the 'anthropomorphic' sculptures are so highly stylised that it is difficult to understand what is being depicted. They have been interpreted as both humans and animals or birds. In our opinion, it is most likely that they were anthropo-zoomorphic images. Such figurines can be interpreted both as images of people wearing masks, and as creatures that are endowed with both human and animal features. The plot of a human and animal merger, or transformation of one into the other, is quite widespread in all forms of art, including sculpture, and in beliefs from ancient times to the present ${ }^{41}$. Ethnographic examples can be found among the Eskimos, in which the connecting point between the different creatures is the neck (the junction of the cervical vertebrae and skull). Eskimos considered this point to be the reservoir of the animal's soul. ${ }^{42} \mathrm{~A}$ combination of anthropomorphic and zoomorphic features has also been observed on many central and eastern European Stone Age clay figurines. One example is a female body with an animal head - a kind of 'transitional form' between humans and beasts. ${ }^{43}$ Examples of such 'merged' images exist in Estonia as well. The first is the figurine from Valma (Fig. 12: 1; Appendix 1: 1) which was interpreted as being both a human and a bear ${ }^{44}$. Another fragment of a figurine from Lommi III (Fig. 12: 8; Appendix 1: 19) was previously interpreted as a bird's head ${ }^{45}$, but analogies with anthropomorphic figurines with long noses from Finland ${ }^{46}$ allow us to conclude that this could also be anthropomorphic.

Zoomorphic figurines are not numerous in the Baltic region and Finland. They are mainly represented by images of tetrapod

41 E.g. E. E. Fradkin, "Polieykonicheskaya skul'ptura iz verhnepaleoliticheskoy stoyanki Kostenki I", Sovetskaya etnografiva 1 (1969), 135-142.

42 E. A. Glinskiy, Darian A. Sergeev, E. E. Fradkin, "Kit v predstavleniyakh beringomorskih eskimosov", Sovetskaya etnographiya, 4 (1982), 114

43 Eszter Bánffy, "Neolithic Eastern and Central Europe", The Oxford Handbook of Prehistoric Figurines, ed. by Timothy Insoll (Oxford: Oxford University Press, 2017), 720-722.

44 Tarmo Kulmar, "Eesti muinasusundi hingefenomenoloogiast, III: hingekujutlused Eest kiviaja arheoloogiaaineses", Akadeemia, 9 (1992), 1876; Butrimas, "Human figurines in EasternBaltic Prehistric Art", 23.

45 Jaanits, "Novye dannye po neolitu Pribaltiki", 195-196; Jaanits, Poseleniya epohi neolita i rannego metalla v priust'e r. Emayigi (Estonskaya SSR), 275, 277.

46 Miettinen, "En idol från Hietaniemi i Luopioinen", Fig. 5. mammals, including Cervidaes, beavers and even martens, bears and snakes. ${ }^{47}$ One snake was found in Estonia at Sindi-Lodja III (Appendix 1: 24). Other figurines that have been found include highly stylised four-legged (quadruped) animal figurines. ${ }^{48}$ The Estonian and Ingrian material includes two such figurines found from the Lommi III and Naakamäe sites (Fig. 12: 6, 7; Appendix 1: 16, 17).

There are fewer than ten clay figurines that have been interpreted as possible sea creatures or fishes in the European forest belt. One fragment of figurine from Rääkkylä Pörrinmökki Comb Ware site in Finland is rather vague and could be a fish, whale or seal. ${ }^{49}$ Another figurine interpreted as a seal is from the Lilljerget settlement site in northern Sweden ${ }^{50}$, and one is from the Jettböle settlement site on the Åland Islands ${ }^{51}$. There is also a clay seal head from the Ajvide cemetery site on Gotland ${ }^{52}$, two seal figurines from the Ire site on Gotland ${ }^{53}$ and two more seal-like figurines from Fagervik in Östergötland ${ }^{54}$. In this context, the possible harbour porpoise figurine from Jägala is rare.

The harbour porpoise, which is up to 2 metres in length and weighs about $80 \mathrm{~kg}^{55}$ has been hunting animals in the Baltic Sea since the the Stone Age. Along the eastern coastal areas of the Baltic Sea, the

47 E.g. Oscar Almgren, "Nordiska stenåldersskulpturer", Tidskrift för svensk antikvaris forskning, 2 (1907), 114-115; Torsten Edgren, "Einige neue Funde von kammkeramischen Vogelbildern und Tierskulpturen aus Ton", Finskt Museum, 73 (1966), 18-24; Edgren, "Kivikausi", 60; Pesonen, "Zoomorphic clay figurines from two Stone Age sites in Rääkylä, North Karelia",

48 Taisto Karjalainen, "Lintutornin lintu”, Muinaistutkija, 3 (Helsinki, 1997), 23.

49 Pesonen, "Zoomorphic clay figurines from two Stone Age sites in Rääkylä, North Karelia", 185, Fig. 3.

50 Anette Färjare, “Lillberget - en 6000 årig boplats väcks till liv", Norrbotten, 1995 (1996), $84-99$.

51 Jan Storå, "Reading bone. Stone Age hunters and seals in the Baltic", Stockholm Studies in Archaeology, 21 (Stockholm, 2001), 50.

52 Göran Burenhult, "Säijägare och svinherdar på Ajvide", Ajvide och den modern arckeölogil, ed. by G. Burenhult (Fölkoping, 1997), 19

53 John Nihlén, "Föremål av bränd lera från stenåldern”, Fornvännen (1925), 215-217.

54 Janzon, "Zoomorphic clay figurines and beads from Ire, Hangvar parish, Gotland", 2-3.

55 Aul, Ling, Paaver, Eesti NSV imetajad, 276. 
bones of harbour porpoises have been found in several settlement sites in Finland ${ }^{56}$, Estonia ${ }^{57}$ and Latvia ${ }^{58}$.

Based on geological and archaeological findings, the harbour porpoise migrated to the Baltic Sea a few thousand years earlier ${ }^{59}$, did not become an important hunting animal along the eastern coast of the sea until the end of the 4th millennium calBC. In Estonia, bones of harbour porpoises have been found in Stone Age sites on the coast of the mainland and on the islands. A significant portion of the excavated animal bones in the Tallinn Vabaduse väljak settlement site on the coast of the mainland, which date approximately is from 3100-2800 years calBC, and the Naakamäe site on the Saaremaa island, which dates is from 3300-3200 years calBC, are bones of harbour porpoises ${ }^{60}$. The animal bones found in Jägala have not been analysed so far. The settlement sites with harbour porpoise bones in southern Finland and the Åland Islands also dates from the end of the 4th millennium and beginning of the 3rd millennium calBC ${ }^{61}$

Ornithomorphic clay figurines of the Baltic territories only depict water birds, such as ducks or loons. ${ }^{62}$ The Stone Age settlement sites in eastern and northern Europe were often situated on seashores or 56 Pirkko Ukkonen, Shaped by the Ice Age. Reconstructing the history of mammals in Finland Pesonen, Vantaan esihistoria (Vantaa: Vantaan kaupunki, 2008), 317. 57 Lembi Lõugas, Post-Glacial development of vertebrate fauna in Estonian water bodies. A palaeozoological study. $\mathrm{PhD}$ thesis (Tartu: University of Tartu, 1997), Tab. 3; Lembi Lõugas Teresa Tomek, "Marginal effect at the coastal area of Tallinn Bay: the marine, terrestrial and avian fauna as a source of subsistence during the Late Neolithic", Man, his time, artefacts, and pollection of articles dedicated to Richard Indreko, ed. by Kristiina Johanson, Mari Tõrv (Tartu: University of Tartu, Institute of History and Archaeology, 2013), 463-485.

58 Ilga Zagorska, "Sea mammal hunting strategy in the Eastern Baltic", Lietuvos Archeologija, 19 (2000), 275-285.

59 Robert S. Sommer, Juliane Pasold, Ulrich Schmölcke, "Post-Glacial immigration of the harbour porpoise (Phocoena phocoena) into the Baltic Sea", Boreas, 37 (2008), 458-464; .

60 Lembi Lõugas, Kerstin Lidén, D. Erle Nelson, "Resource utilization along the Estonian coast during the Stone Age", Coastal Estonia. Recent Advances in Enviromental and Cultural History, ed. by Tony Hackens, Sheila Hicks, Valter Lang, Urve Miller, Leili Saarse (Rixensar: PACT Belgium, 1996), 402; Lougas, Tomek, "Marginal effect at the coastal area of Tallinn Bay
the marine, terrestrial and avian fauna as a source of subsistence during the Late Neolithic", 467 61 Storå, "Reading bone. Stone Age hunters and seals in the Baltic", 38, 40; Leskinen, Pesonen, Vantaan esihistoria, 317.

62 Rimute' Rimantienè, Šventoji, Narvos kultŭros gyvenvietès (Vilnius: Mokslas, 1979), 110, Fig. 87: 7; Karjalainen, "Lintutornin lintu", 23. beside lakes and rivers, where small water birds commonly lived. ${ }^{63}$ Various types of ornithomorphic water bird images (on clay and wooden vessels and petroglyphs, for example) have usually been interpreted as ducks, geese or swans. ${ }^{64}$ Only one fragment of an ornithomorphic figurine - the head of water bird - was found on the Lommi III site in Ingria (Fig. 12: 5; Appendix 1: 18).

\section{DISCUSSION}

Clay figurines from the European forest belt have often been compared to the sculptures of southern and central Europe, and undoubtedly there are a number of common features. ${ }^{65}$ Apparently, this happens because it is the closest Stone Age complex that can be used for comparison. Despite repeated references to these materials and attempts to explain the origins of the figurines of the forest belt as being culturally influenced by the more southerly parts of Europe ${ }^{66}$ nobody has been able to prove any clear connection.

The appearance of clay sculpture in southern and central Europe Eastern Asia, etc., is strongly associated with the emergence of a farming economy ${ }^{67}$ The situation is different for the forest belt. Although there is some evidence that single pollen of cereals did

63 Linas Daugnora, Rasa Bilskiene, Anne Karin Hufthammer, "Bird remains from Neolithic and Bronze Age settlements in Lithuania", Acta zoologica cracoviensia, 45 (2002), 233-238; Baltic Sea Islands in the Neolithic (Hiiumaa, Saaremaa, Gotland and Aland)", Feathers, grit and symbolism. birds and humans in the ancient old and new worlds. Proceedings of the 5th Meeting of the ICAZ Bird working group in Munich, 267.-28.7.2004. Documenta Archaeobiologiae 3 (Rahden, 2005), 179-198.

64 Lembit Jaanits, “Jooni kiviaja uskumustest”, Religiooni ja ateismi ajaloost Eestis. Artiklite kogumik II (Tallinn: Eesti Riiklik Kirjastus, 1961), 43; Nina N. Gurina, "Vodoplavayuschay ptitsa v iskusstve neoliticheskih lesnykh plemen", Kratkiye soobscheniya Instituta Arkheologii, 131 (1972), 36-45; Petro Pesonen, "Rääkkylän joutsenet ja muita kampakeramiikan linnunkuvia", Kirjoitelmia arkeologian alalta. Kentälttä poimittua 3. Museoviraston arkeologian osaston iskusstve neolita - , elita lesnoy zony Vostochnoy Evropy”, Rossijskaya arkheologiya, (2010), 5-17.

65 E.g. Äyräpää, "Kampakeraamisen kulttuurin savikuviot”, 111-115; Jaanits, "Jooni kiviaja uskumustest", 23-24.

66 For the ideas and discussion, see e.g. Almgren, "Nordiska stenåldersskulpturer", 123, Europaeus "Uusia kivikauden taidelöytöï̈", 87; Äyräpää, "Kampakeramisen kulttuuri savikuviot", 116; Núñez, "Clay figurines from the Xland islands and mainland Finland", 21

67 E.g. David Wengrow, “"The changing face of clay': continuity and change in the transition from village to urban life in the Near East", Antiquity, 72 (1998), 784; Doug Bailey, "Touch and the cheirotic apprehension of prehistoric figurines", Sculpture and Touch, ed. by Peter Den (London: Ashgate Publishing, 2014), 28. 
exist during this period, ${ }^{68}$ it was still a world of hunter-gatherers. Differences in sculptural images are also evident: in the farming society, anthropomorphic figurines totally dominate, while in the forest belt there is a significant number of zoomorphic and ornithomorphic images. In the farming society, a great deal of attention was paid to the gender characteristics of the figurines, which are therefore pronounced. On the other hand, the 'forest' clay figurines are usually asexual and highly stylised, etc.

We tend to support the researchers who do not think that the 'forest' figurines originated in southern and central Europe.${ }^{69}$ Rather, it was probably an independent phenomenon, a universal cultural idea. Clay sculptures have appeared from time to time in different parts of the world from the Upper Palaeolithic period. ${ }^{70}$ Why couldn't the same thing have happened in the European forest belt during the Stone Age? Apparently, the notable migration, as proven among other things by ancient DNA, ${ }^{71}$ from the neighbouring territories in the East to the Eastern Baltic and Finland at the beginning of the $4^{\text {th }}$ millennium calBC, and the resulting development of the Comb Ware culture as well as the extensive relationships between individuals and communities seen in the material culture (including the exchange of raw materials and artefacts) thereafter ${ }^{72}$ were the reasons behind the extensive distribution and uniformity of the clay figurines.

Stone Age clay figurines from all the territories have mainly been attributed to beliefs and cults. They have been interpreted as gods/goddesses, amulets, totems, idols, human substitutes, or even

68 E.g. Aivar Kriiska, "From hunter-gatherer to farmer. Changes in the Neolithic economy and settlement on Estonian territory", Archaeologia Lituana, 4 (2003), 11-26.

69 E.g. Edgren, "Kivikausi", 59.

70 E.g. Pamela B. Vandiver, Olga Soffer, Bohuslav Klima, Jiři Svoboda, "The Origin of Ceramic Technology at Dolni Věstonice, Czechoslovakia”, Science, 246 (4933) (1989), 1002-1008.

71 Alissa Mittnik, Chuan-Chao Wang, Saskia Pfrengle, Mantas Baubaras, Gunita Zarina, Frederik Hallgren, et al., "The genetic prehistory of the Baltic Sea region", Nature Somnications, "E2 (9) (2018), 1-11, Lehi Sang, Livi Varul, Christana Lyn Scheib, Jesper the Steppe", Current Biology, 27 (14) (2017), 2185-2193.

72 E.g. Aivar Kriiska, "Foreign Materials and Artefacts in the 4th and 3rd Millennia BCE Estonian Comb Ware Complex", When Gods Spoke. Researches and Reflections on Religious Phenomena and Artefacts. Studia in honorem Tarmo Kulmar. Studia Orientalia Tartuensia, Serie Nova VI (Tartu. University or Tartu Press, 2015), 107-124, Aleksandr M. Zhulnikov, "Exchange of Amber in Northern Europe in the III Millennium BCE as a Factor of Social Interactions", Estonian Journal of Archaeology, 12 (1) (2008), 3-15. enemies'. ${ }^{73}$ They could also be interpreted as being related to medical magic; ${ }^{74}$ associated with the cult of spirits and ancestors; ${ }^{75}$ linked to shamanism ${ }^{76}$ or related to burial rituals ${ }^{77}$. In the Finnish tradition, all the clay figurines are called 'idols' (idoli) ${ }^{78}$ which is already an interpretative term. On the other hand, many of these interpretations are criticised as being 'anecdotal', ${ }^{79}$ since no serious evidence exists. We assume that these items are definitely related to activities that are usually defined as sacral (in general), but cannot be sure of any concrete interpretations.

Ornamentation covering some of the clay figurines could be not less important than the figurines themselves. ${ }^{80}$ Some figurines of the forest belt were painted with ochre, ${ }^{81}$ but this did not occur at Jägala, although some ochre pieces were found southeast of the pit-house At least ten figurine fragments (probably from six different items) from Jägala are ornamented with pits, notches and lines, which can indicate clothes, hair, fur, etc.

73 Marija Gimbutas, The Gods and Goddesses of Old Europe, 6500-3500 B.C.: Myths, Legends and Cult Images (London: Thames and Hudson, 1982); Janzon, "Zoomorphic clay igurines and beads from Ire, Hangvar parish, Gotland", 10; Bożena Wyszomirska, "Figurplastik och gravskick hos nord-och Nordösteuropas neolitiska fangstkulturer", Acta archaeologica Cambridge Archaeological Journal, 6, 2 (1996), 281-307; Pesonen, "Zoomorphic clay figurines from two Stone Age sites in Rääkylä, North Karelia", 188-189; Butrimas, "Human figurines in Eastern-Baltic Prehistric Art", 28; Ekaterina Kashina, "Ceramic anthropomorphic sculpture of the East European forest zone", Ceramics before farming: the dispersal of pottery among prehistoric Eurasian hunter-gatherers, ed. by Peter Jordan, Marek Zvelebil (Walnut Creek: Left Coast Press, 2009), 281-297; Richard G. Lesure, Interpreting Ancient figurines: context, comparison, and prehistoric art (Cambridge: Cambridge University Press, 2011).

74 Jaanits, "Jooni kiviaja uskumustest", 58.

75 Matti Huurre, 9000 vuotta Suomen esihistoriaa. 3d edition (Helsinki: Otava, 1983), 61.

76 Núñez, "Clay figurines from the Åland islands and mainland Finland", 25.

77 Petri Halinen, "Burial Practices and the Structure of Societies during the Stone Age in Finland", Dig it all. Papers dedicated to Ari Siiriäinen, ed. by Matti Huurre (Helsinki: Finnish Antiquarian Society, 1999), 175.

78 E.g. Edgren, "Kivikausi”, 58

79 Doug Bailey, "Southeast European Neolithic figurines: beyond context, interpretation and meaning", The Oxford Handbook of Prehistoric Figurines, ed. by Timothy Insoll (Oxford Oxford University Press, 2017), 826-833.

80 Foss, "Drevneyshaya istoriya severa Evropeyskoy chasti SSSR", 69-77; Wyszomirska, "Figurplastik och gravskick hos nord-och Nordösteuropas neolitiska fangstkulturer", 127; Loze, "Northern Kurzeme Neolithic miniature plastic art in clay", 79-82.

81 Äyräpää, "Kampakeraamisen kulttuurin savikuviot", 83; Wyszomirska, "Figurplastik och gravskick hos nord-och Nordösteuropas neolitiska fangstkulturer", 127; Núñez, "Clay figurine from the Åland islands and mainland Finland”, 19, 21. 
The raw material, i.e. clay, probably also played an important role in the symbolism of these items. A number of papers have been devoted to the consideration of this issue, highlighting the complicated attitude of people in ancient times, as well as in the modern world toward this material, which has different properties (the plasticity of moulding mass, its ability to harden and change its properties during firing, the fragility of the finished product, etc.). Clay is able to create an 'emotional connection' with humans, which occurs through an interaction with the earth and the manual working - a kind of meditation, and at the same time receiving information through touch..$^{82}$ Besides, if 'touch is a way of knowing' these items could also serve as teaching tools. ${ }^{83}$

Zoomorphic figurines from the European forest belt where huntergatherers lived in 4-3 millennia calBC were primarily interpreted as being connected to hunting magic, and the anthropomorphic figures to the hunters themselves. ${ }^{84}$ For example, the harbour porpoise figurine from Jägala can be connected to sea hunting. Since most of the figurines were found inside the dwellings and in the cultural layer of the settlement sites, they were primarily associated with the home and fertility cults. ${ }^{85}$ Since pottery making is traditionally seen as women's work, the manufacture of clay figurines tends to be attributed to women. Therefore, it is possible that some should be associated with female rituals, ${ }^{86}$ while some of the figurines could be toys. But all the figurines can undoubtedly be multifunctional, and, in fact, we will never know their real purpose. ${ }^{87}$

82 Alexandra Timmons, Elaine MacDonald, "'Alchemy and magic': the experience of using clay for people with chronic illness and disability", British Journal of Occupational Therapy, 71 (3) (2008), 86-94; Per Ditlef Fredriksen, "When knowledges meet: engagements with clay and soi Nordqvist, "A northern Neolithic? Clay work, cultivation and cultural transformations in the Nordqvist, "A northern Neolithic? Clay work, cultivation and cultural t.
Boreal zone of North-Eastern Europe, c. 5300-3000 BC", 29-30, 35-37.

83 Bailey, "Touch and the cheirotic apprehension of prehistoric figurines", 33

84 Wyszomirska, "Figurplastik och gravskick hos nord-och Nordösteuropas neolitiska fangstkulturer", 64 .

85 Ilze Loze, "Glinjanie figurki iz neoliticheskih stojanok Vostochnoj Pribaltiki”, Sovetskaya Etnografiya, 3 (1970), 61; Oshibkina, Neolit Vostochnogo Prionezhya, 104.

86 Kashina, "Ceramic anthropomorphic sculptures of the East European forest zone", 294.

87 Bailey, "Touch and the cheirotic apprehension of prehistoric figurines", 28
Most of the figurines found on Stone and even Bronze Age sites are broken. ${ }^{88}$ It has been suggested that they were intentionally broken, as part of a ritual, and perhaps these figurines, or at least some of them, were intentionally made to be destroyed later. ${ }^{89}$ This cannot easily be proven but some evidence of intentional breakage exists for different territories and periods. This includes eastern and central Europe in the early 5th millennium BC, the Near and Middle East and Mexico in the 2nd to late 1st millennia BC, as well as other countries in Mesoamerica. ${ }^{90}$ The question of the intentional breakage of items in ancient times, including the Stone Age sculptures in farming societies, was widely examined considering the size and form of the items and 'structured deposition' of fragments. ${ }^{91}$ It was determined that these items could not have been accidently broken. ${ }^{92}$ However, some scepticism about deliberate breakage also exists. ${ }^{93}$

Having studied the fragments of figurines from Jägala, we have also surmised that their fragmentation was not accidental. The figurines are small and most are sculptured from one piece of moulding mass. They could not break by themselves or by accidentally breaking by

88 E.g. Georgi I. Georgiev, "Glavni periodi v razvitieto na kulturata prez neolita i mednata epoha v Bolgaria v svetlinata na nay-novite arkheologicheski prouchvania", Światowit, XXII (1960), 319; Marco Ramazzotti, "The Mimesis of a world. The early and middle Bronze clay figurines from Ebla-Tell Mardikh", Figuring out the figurines of the ancient Near East, ed. by Stephanie M. Langin-Hooper. Occasional papers in coroplastic studies 1 (2014), Tabs. I: B-D Bailey, "Southeast European Neolithic figurines: beyond context, interpretation, and meaning", $827-829$.

89 Jaanits, "Jooni kiviaja uskumustest", 58; Janzon, "Zoomorphic clay figurines and beads from Ire, Hangvar parish, Gotland", 10; Loze, "Northern Kurzeme Neolithic miniature plastic religious belief", Documenta Praehistorica XXXIV (2007), 122; Goce Naumov "Together We religious belief", Documenta Praehistorica XXXIV (2007), 122; Goce Naumov, "Together We figurines, Republic of Macedonia", Anthropomorphism and symbolic behaviour in the Neolithic and Copper age communities of South-Eastern Europe, ed. by Constantin-Emil Ursu, Stanisla Țerna (Suceava: Muzeul Bucovinei, 2014), 168-170.

90 Wengrow, “"The changing face of clay': continuity and change in the transition from village "Furban life in the Near East ,786, Nathan J. Meissner, Katherine E. South, Andrew K. Balkansky,

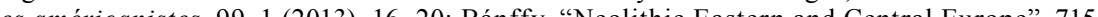

91 E.g. Marko Porčić, "Contextual analysis of fragmentation of the anthropomorphic figurine from the Late Neolithic site of Selevac", Issues in Ethnology and Anthropology, 7 (3) (2012), 809-827; Naumov, "Together We Stand - Divided We Fall: the representation and fragmentatio among Govlevo and Zelonikovo figurines, Republic of Macedonia", Bailey, "Southeast Europea Neolithic figurines: beyond context, interpretation, and meaning", 827-829.

92 John Chapman, Bisserka Gaydarska, Parts and Whole: Fragmentation in Prehistoric Context (Oxford: Oxbow Books, 2007), 8

93 E.g. Richard G Lesure, "The Goddess Diffracted. Thinking about the Figurines of Early Villages", Current Anthropology, 43, 4 (2002), 590. 
falling - none of the surfaces are hard enough. Of course, most of the finds from Stone Age sites are broken: the clay vessels, bone and stone tools, etc., but in contrast to the household items used in 'everyday life', the clay figurines could not have been broken in the course of daily use. However, it should be noted that the continuous habitation on the settlement site contributed to the further destruction of fragments deposited in the cultural layer. Some parts of the figurines are missing. The fragments cannot be reconstructed into whole figurines. In the case of the Jägala site, we cannot be sure that missing parts are not hidden in the undug part of the pit-house. However, this is also true of numerous other examples from clear contexts. The fate of the missing parts is unknown, although some unprovable theories do exist suggesting, for example, that parts of figurines could have been used for exchange as symbolic acts of contract, agreement or trust between 'men or groups of people'.94 However, based on some ethnographic parallels, cult items were usually not transferred or exchanged. ${ }^{95}$

To test the idea that the clay figurines from Jägala were intentionally broken, all the fragments were examined under a magnifying glass to look for traces of a deliberate impact. Although the figurine fragments had been rounded by the sand, traces of chipped flakes were found on the edges of some of them (Fig. 13). Further study under a microscope showed that the flakes on the items appeared in ancient times and were rounded, as was the rest of the surface. In many cases, deep cracks diverging to the sides were revealed at the faults. Given the density of the figurines and their small size, it is impossible to assume this breakage was random in nature. It could only have resulted from a deliberate impact. We are of the opinion that the position of broken figurines among other finds in the cultural layer of the Jägala site suggests that they were no longer in use and were thrown away after being broken.

The firing temperature for the clay figurines could differ. The composition of moulding clay mass could be the same as for the pottery, or it could be different with specific admixtures such as

94 Wengrow, “"The changing face of clay': continuity and change in the transition from village to urban life in the Near East", 785 .

95 Oshibkina, Neolit Vostochnogo Prionezhya, 104.

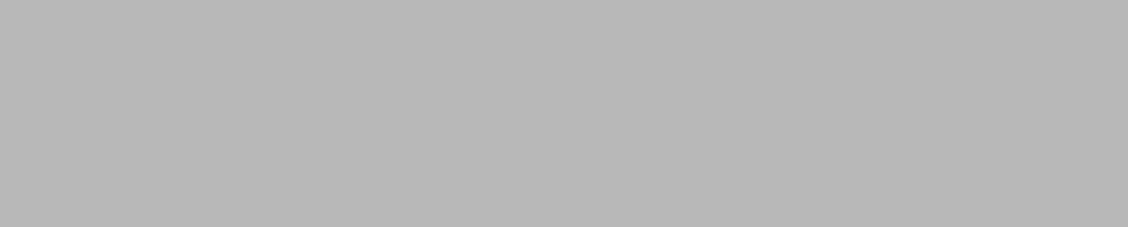

FIG. 13. TRACES OF CHIPPED FLAKES ON THE EDGES OF FIGURINE FRAGMENTS FROM JÄGALA. PHOTOS: RIINA RAMMO.

crushed bone, for example, or it could be without artificial temper. ${ }^{96}$ At Jägala, different compositions of moulding clay mass with various combinations of admixture, probably mainly natural, were found. Based on the colour and structure of the fragments, the figurines were fired at different temperatures (ca 700-900 ${ }^{\circ} \mathrm{C}$ ), for example, the shell remains in the clay of the fragments from group 10 indicate that the firing temperature did not exceed $800-820^{\circ} \mathrm{C} .{ }^{97}$

Experimental research related to the intentional breakage of the fired clay samples, fired at temperatures of 700 to $1000^{\circ} \mathrm{C}$, revealed that traces of the strikes made with different hammers, i.e. a hard one (a flint lump) and a soft one (an elk antler), are almost identical. When striking the handheld plates, a limited number of small pieces and flakes on the opposite side were caused by the strike. A strike to an edge only resulted in flakes on the surface, while striking it in the centre resulted in a few large fragments with a straight breakage line and flakes. Strong impacts also caused deep cracks (Fig. 14AD). Strikes to items held on the wood anvil resulted in a number of small pieces and ragged edges on the larger ones (Fig. 14E-H).

The results of the experiment let us conclude that two main types of breakage have occurred on the Jägala clay figurines. The first type, which is characterised by edge flakes and cracks and present on the

96 Janzon, "Zoomorphic clay figurines and beads from Ire, Hangvar parish, Gotland", 12; Maiia P. Zimina, "Zapad Russkoy ravniny", Iskusstvo kamennogo vek (Lesna zona Vostochnoy sculptures of the East European forest zone", 287.

97 Volli Kalm, "X-ray diffraction analysis of Neolithic ceramics: Examples from the Narva area, South-Eastern Coast of the Gulf of Finland", Coastal Estonia. Recent Advances in Environmental and Cultural History, ed. by Tony Hackens, Sheila Hicks, Valter Lang, Urve Miller, Leili Saars (Rixensart: PACT Belgium, 1996), 92. 


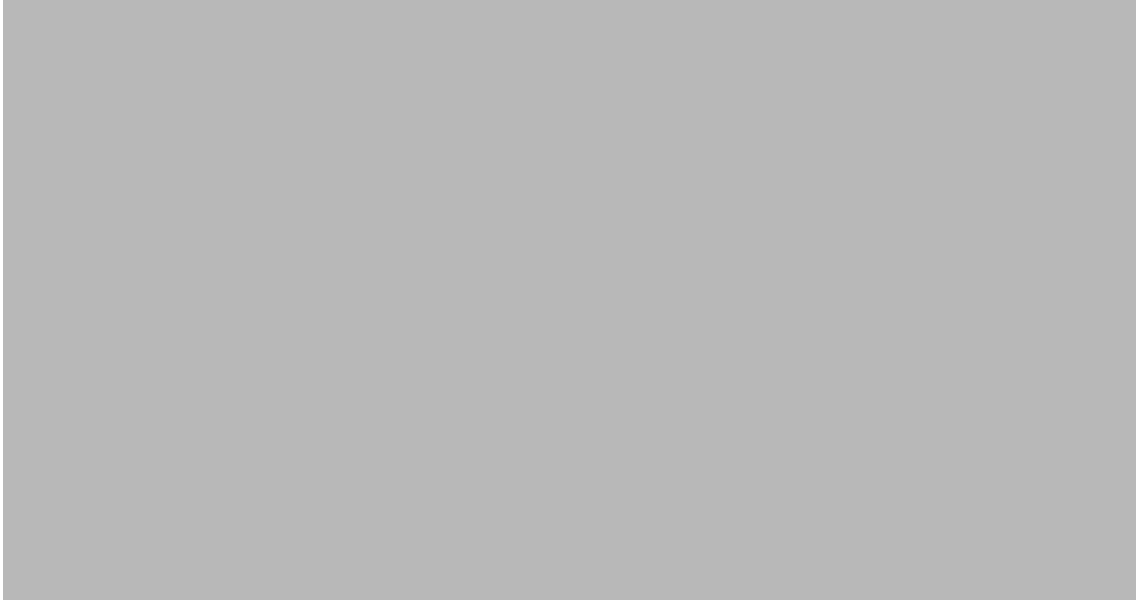

FIG. 14. EXPERIMENTAL BREAKAGE OF BURNT CLAY SAMPLES. (A) A CLAY PLATE FIRED AT $800^{\circ} \mathrm{C}$. (B) A STRIKE TO THE CENTRE OF A HANDHELD PLATE WITH A HARD HAMMER (FLINT FLAKES ON THE EDGES OF THE FRAGMENT AND A DEEP CRACK. (E) A CLAY PLATE FIRED AT $850^{\circ} \mathrm{C}$. (F) A STRIKE TO THE EDGE OF THE PLATE BEING HELD ON A WOOD ANVIL WITH A SOFT HAMMER (ELK ANTLER). (G) THE RESULT OF THE BREAKAGE WITH A SOFT HAMMER. (H) BROKEN EDGE OF THE FRAGMENT. PHOTOS: AIVAR KRIISKA, IRINA KHRUSTALEVA,

relatively large fragments of presumed anthropomorphic figurines (Fig. 13A, B), was most probably caused by a strong strike to the item while it was being held in the hand. Another type of breakage, which is characterised by strong fragmentation and 'lost parts' of the figurines, resulted from a strike to the item while it was held on an anvil (wooden or stone).

With few exceptions, most of the clay figurines of the European forest belt were found in the cultural layers of the settlement sites. To date, only two cases of burial positions have been documented: one 'bent' anthropomorphic figurine was found at the Zvejnieki burial ground in Latvia (burial 221) ${ }^{98}$ and another similarly shaped figurine was in the Sakhtysh IIA burial ground in Russia (burial $61)^{99}$. In general, for the territory being researched, there are only a few reliably established contexts for the clay figurines that can be

98 Francis Zagorskis, Zvejnieku akmens laikmeta kapulauks (Riga: Zinatne, 1987), 49, 77-78, Att. 30 .

99 Elena L. Kostyleva, Alexander V. Utkin, "Neo-eneoliticheskiye mogilniki Verkhnego Povolzhya i Volgo-Okskogo mezhdurechya", Planigraficheskiye i khronologicheskiye struktur. (Moskva: Taus, 2010). explained by the specifics of the excavation technique, i.e. the finds were collected from squares of $1 \times 1$ metre or even larger, and by the long-standing attitude that this category of find are ('beautiful') things ${ }^{100}$, rather than archaeological sources. In addition, some of the less expressive fragments of figurines were not identified and documented during excavations, but rather in the process of further study of the collection of find $\mathrm{s}^{101}$. However, in some settlement sites they are clearly associated with dwellings, for example the Peski IVa and Ileksa I sites in Kareliaa ${ }^{102}$, Rääkkylä Vihi $1^{103}$ and Outokumpu Lintutorni ${ }^{104}$ in Finland, Kubenino ${ }^{105}$ in Northwestern Russia and Sarnate in Latvia ${ }^{106}$. There are also some links to buildings that are less concrete. For example, the fragments of clay figurines on the Paimio Toispuolojannummi site in Finland were found in the 'dwelling depressions' or on the edge thereof. ${ }^{107}$ The information that the figurines from the Pūrciems site (Latvia) were located inside dwellings ${ }^{108}$ should be treated with a degree of caution, since the proposal that dwellings were even present still awaits serious evidence $^{109}$.

The Stone Age clay figurines were found predominantly in dwelling settlements rather than temporary campsites, although these were also excavated. Since, in a number of cases, the figurines were located not singly but several were found in one context at the site, a theory developed about the existence of certain 'sets' of clay

100 Janzon, "Zoomorphic clay figurines and beads from Ire, Hangvar parish, Gotland", 4; Bánffy, "Neolithic Eastern and Central Europe", 705.

101 E.g. Janzon, "Zoomorphic clay figurines and beads from Ire, Hangvar parish, Gotland", 11 102 Anatoly P. Zhuravlev, "Glinyanaya figurka vodoplavayuschey ptitsy na stoyanke Ileksa I", Sovetskaya arkheologiya, 4 (1982), 216; Aleksandr M. Zhulnikov, Petroglify Karelii. Obraz mira i miri obrazov (Petrozavodsk: Skandinavija, 2006), 190.

103 Petro Pesonen, “Vihi - kampakeraaminen asuinpaikka Rääkkylässä”, Muinaistutkija, (1998), 26

104 Karjalainen, "Lintutornin lintu", 23.

105 Foss, "Drevneyshaya istoriya severa Evropeyskoy chasti SSSR", 213

106 Lutsia V. Vankina, Torfyanikovaya stoyanka Sarnate (Riga: Zinatne, 1970), 82, Abb. XXXVI.

107 Europaeus, "Uusia kivikauden taidelöytöjä”, 87.

108 Kashina, "Nabory lepnykh zoomorphnykh skulptur v neolite-eneolite lesnoy zony Vostochnoy Evropy i Finljandii”, 131.

109 Eduards Šturms, Pārskats par izrakumiem Dundagas Purciemā (1936). Manuscript in the Archive of the National Museum of the History of Latvia). 
figurines, which included all the most important images. ${ }^{110}$ Although it is difficult to prove, the fragments of sculptures in Jägala were also located in concentrations. One was linked to the pit-house and another to a large accumulation of other finds that could indicate the outline of an unpreserved structure.

If we consider the main contexts of finding the clay Stone Age sculpture more broadly, e.g. on early farming sites in southern and central Europe, Ukraine, Serbia, etc., they were usually located at settlement sites, mainly in pits or buildings. Sometimes special, probably ritual, buildings stand out among them, but more often the figurines were found near the fireplaces in dwellings or in the farthest corner from the entrance ${ }^{111}$.

\section{CONCLUSION}

Clay figurines in Estonia, and generally throughout the entire European forest belt, date back to $4000-3000$ years calBC and are primarily associated with the Comb Ware cultures. These items were usually found on dwelling settlements and are unknown at temporary camp sites. The originality of the clay figurines found in the European forest belt clearly differentiates them from similar objects in other territories, although a large number of parallels and analogies do exist. However, this does not mean there was direct contact between the populations of the various territories or that one originated from the other. Instead, these similarities can be dictated by the features of the raw material from which the figurines were made, and which, undoubtedly, made its own adjustments to the shape of the product, as well as possibly by the main idea and function of these items. There are no regionally distinctive features in the images and their styles within the European forest belt, and despite their diversity, all these objects clearly fit into a single complex.

Only thirteen clay figurines from Estonia and Ingria have been published before our research. The sculptural fragments found on the
Jägala Jõesuu V settlement site (ca 3200-3100 years calBC) contributed to some old Comb Ware culture sites - which were available during the research process - being revised. As a result, a catalogue of Estonian Stone Age clay figurines and their fragments was compiled and several radiocarbon dates from the sites containing these items are published for the first time. In total 112 unknown early figurines and their fragments were discovered on seven sites, including 91 from Jägala. Jägala is now the most abundant deposit of clay figurines and their fragments in the eastern Baltic, which accounts for more than $70 \%$ of all the figurine pieces found in Estonia and Ingria. These numbers are not final, since not all the sites that potentially contain clay figurines were examined, and the number of these items in Estonia will increase.

Only a few images from Jägala can be reconstructed, at least two of which are presumed to be anthropomorphic (groups 2 and 3) and another zoomorphic (interpreted as a harbour porpoise, group 1). Most of the presumed anthropomorphic figurine fragments are covered with ornamentation (pits, notches and lines). The main parts of the fragments are unidentified, and 69 of them do not weigh more than 1 gram. Only the harbour porpoise figurine was not broken. All the others were highly fragmented. As was determined (at least for the presumed anthropomorphic figurines), the fragmentation was unambiguously deliberate, therefore it can be assumed that some kind of ritual activity was involved.

The figurines at Jägala were found in two concentrations on the settlement site. The first contained the harbour porpoise image and a number of unidentified fragments was located in the western part of the excavated area among a concentration of other finds. The outlines of this concentration could indicate the location of an ancient unpreserved structure. Almost all the other fragments (with just a few exceptions) were situated in the filling of the pit-house. Among them were purposely broken anthropomorphic figurines that most probably indicate ritual activities conducted in the buildings. Thus, the dwelling at Jägala was not only a habitat, but also a sacral place.

110 Kashina, "Nabory lepnykh zoomorphnykh skulptur v neolite-eneolite lesnoy zony Vostochnoy Evropy i Finljandii".

111 Georgiev, "Glavni periodi v razvitieto na kulturata prez neolita i mednata epoha v Bolgaria $\checkmark$ svetlinata na nay-novite arkheologicheski prouchvania", 319; Adam Crnobrnja, "Arrangement of Vinča culture figurines: A study of social structure and organisation", Documenta Praehistorica, 38 (2011), 131-147; Bánffy, "Neolithic Eastern and Central Europe", 718-719. 



\begin{tabular}{|c|c|c|}
\hline 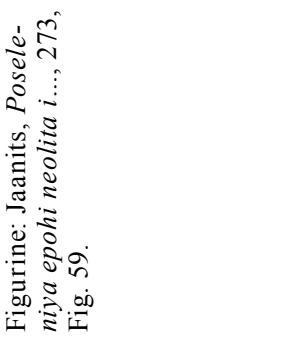 & 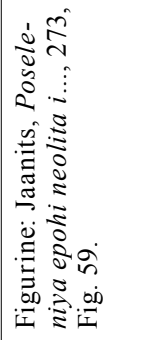 & 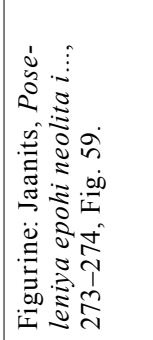 \\
\hline 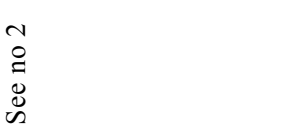 & 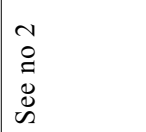 & 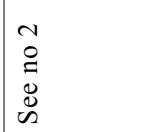 \\
\hline 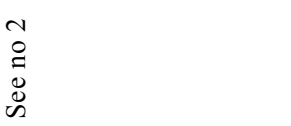 & $\begin{array}{l}\tilde{N} \\
\tilde{D} \\
\tilde{J} \\
\tilde{W}\end{array}$ & 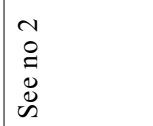 \\
\hline $\begin{array}{l}n \\
x \\
x \\
n \\
x \\
x \\
0 \\
n\end{array}$ & $\begin{array}{l}2 \\
x \\
\infty \\
\stackrel{x}{x} \\
\dot{d}\end{array}$ & $\begin{array}{l}= \\
x \\
\hat{a} \\
x \\
x \\
a\end{array}$ \\
\hline 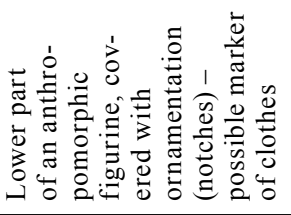 & 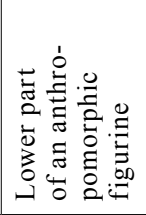 & 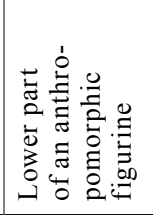 \\
\hline 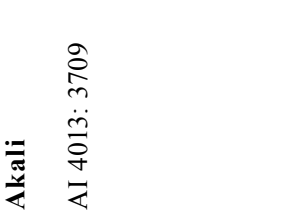 & 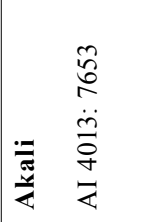 & 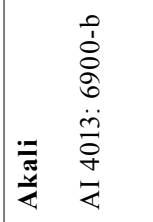 \\
\hline$m$ & $\sigma$ & in \\
\hline
\end{tabular}




\begin{tabular}{|c|c|c|c|}
\hline 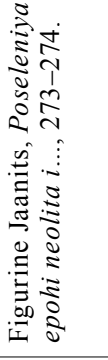 & 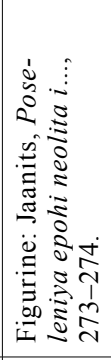 & 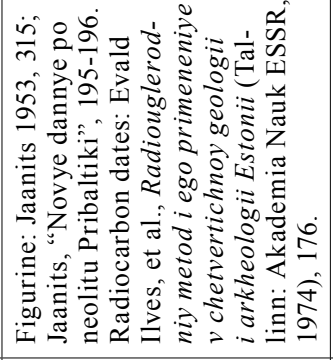 & 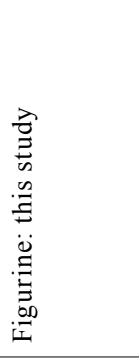 \\
\hline 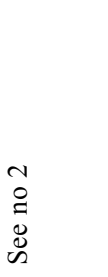 & 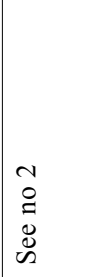 & 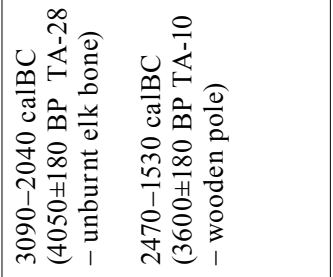 & $\begin{array}{l}\infty \\
0 \\
\Xi \\
0 \\
\infty\end{array}$ \\
\hline $\begin{array}{l}\tilde{} \\
ٌ \\
\Xi \\
\tilde{N} \\
\tilde{n}\end{array}$ & $\begin{array}{l}\tilde{N} \\
ٌ \\
\tilde{D} \\
\mathscr{n}\end{array}$ & 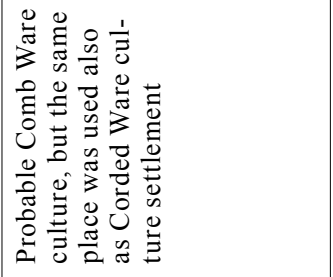 & $\begin{array}{l}\infty \\
\varrho \\
0 \\
\infty \\
\infty\end{array}$ \\
\hline $\begin{array}{l} \pm \\
\dot{x} \\
x \\
\vec{N} \\
x \\
b \\
0\end{array}$ & a. & 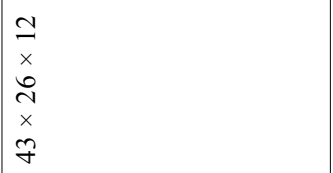 & $\begin{array}{l}= \\
\bar{x} \\
\hat{\lambda} \\
x \\
x \\
0 \\
n\end{array}$ \\
\hline 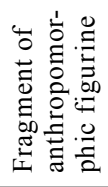 & 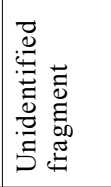 & 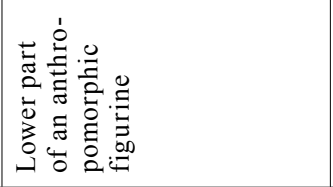 & 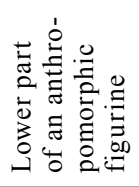 \\
\hline & $\vec{b}$ & & \\
\hline 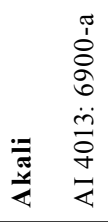 & 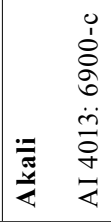 & 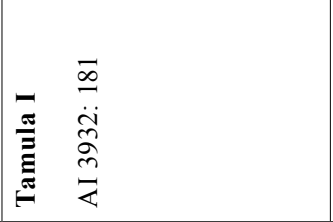 & 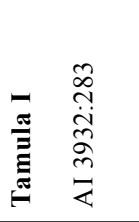 \\
\hline 0 & $n$ & $\infty$ & $a$ \\
\hline
\end{tabular}

\begin{tabular}{|c|c|c|c|}
\hline 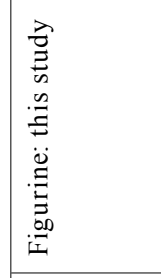 & 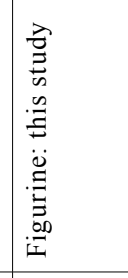 & 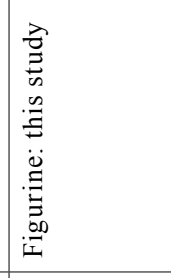 & 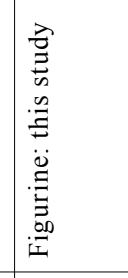 \\
\hline $\begin{array}{l}\infty \\
\vdots \\
\vdots \\
\vdots \\
\vdots \\
\end{array}$ & $\begin{array}{l}\infty \\
\vdots \\
\vdots \\
\vdots \\
\end{array}$ & $\begin{array}{l}\infty \\
\vdots \\
\vdots \\
0 \\
0 \\
0\end{array}$ & 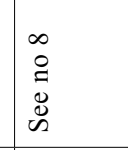 \\
\hline 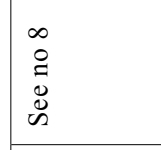 & $\begin{array}{l}\infty \\
0 \\
0 \\
\vdots \\
0 \\
0\end{array}$ & 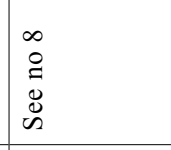 & 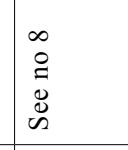 \\
\hline $\begin{array}{ll}0 \\
x \\
x \\
x \\
x \\
x \\
y \\
\end{array}$ & 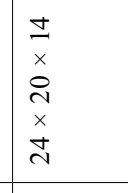 & 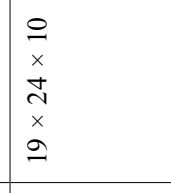 & \begin{tabular}{|l}
$n$ \\
$n$ \\
$x$ \\
$x$ \\
$x$ \\
$y$ \\
$y$ \\
$n$
\end{tabular} \\
\hline 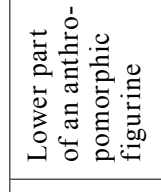 & 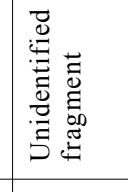 & 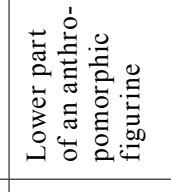 & 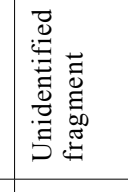 \\
\hline 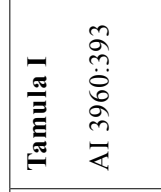 & 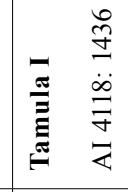 & 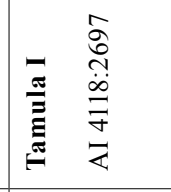 & 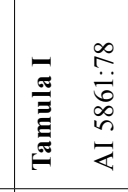 \\
\hline 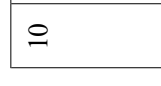 & $=$ & $\cong$ & $\cong$ \\
\hline
\end{tabular}




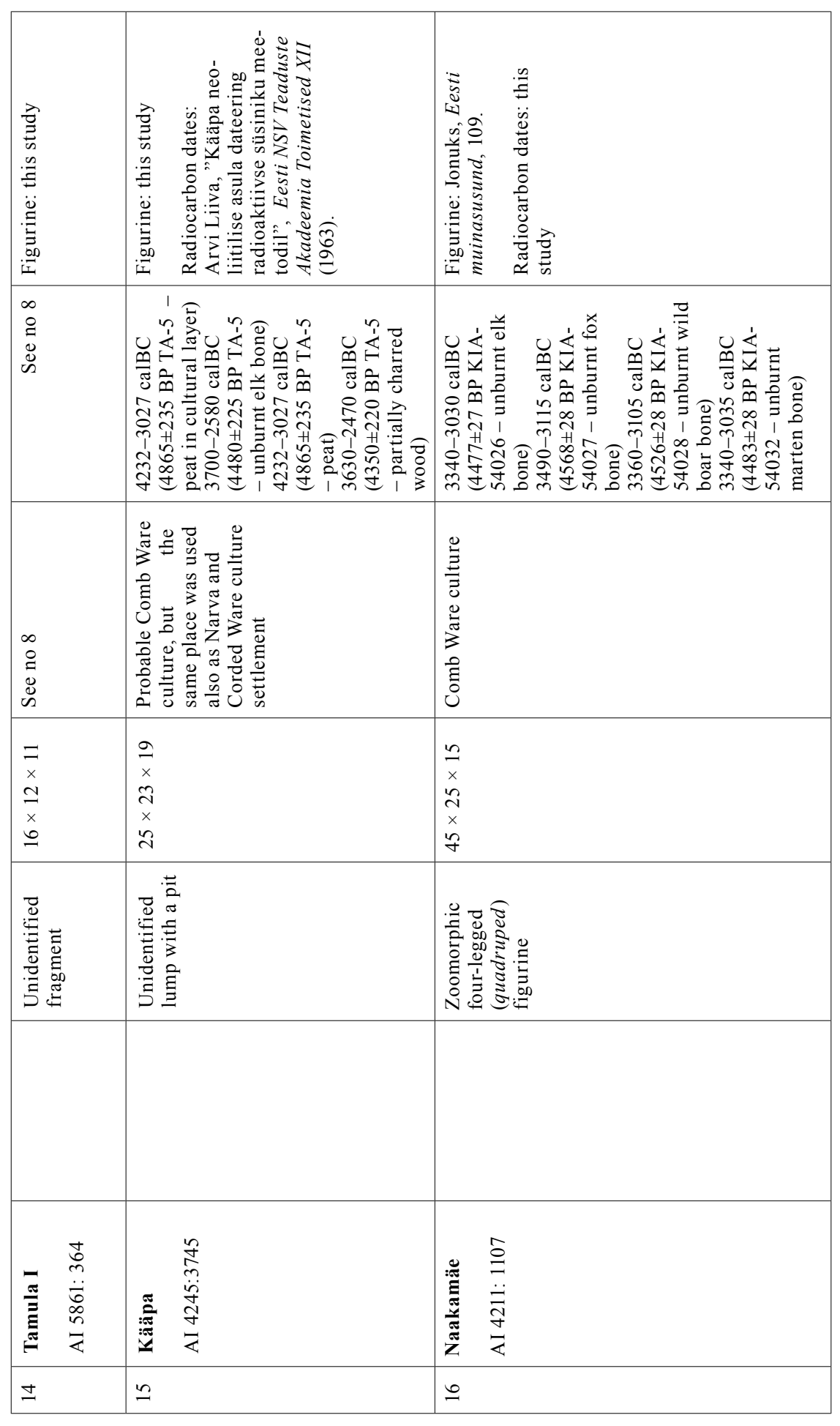

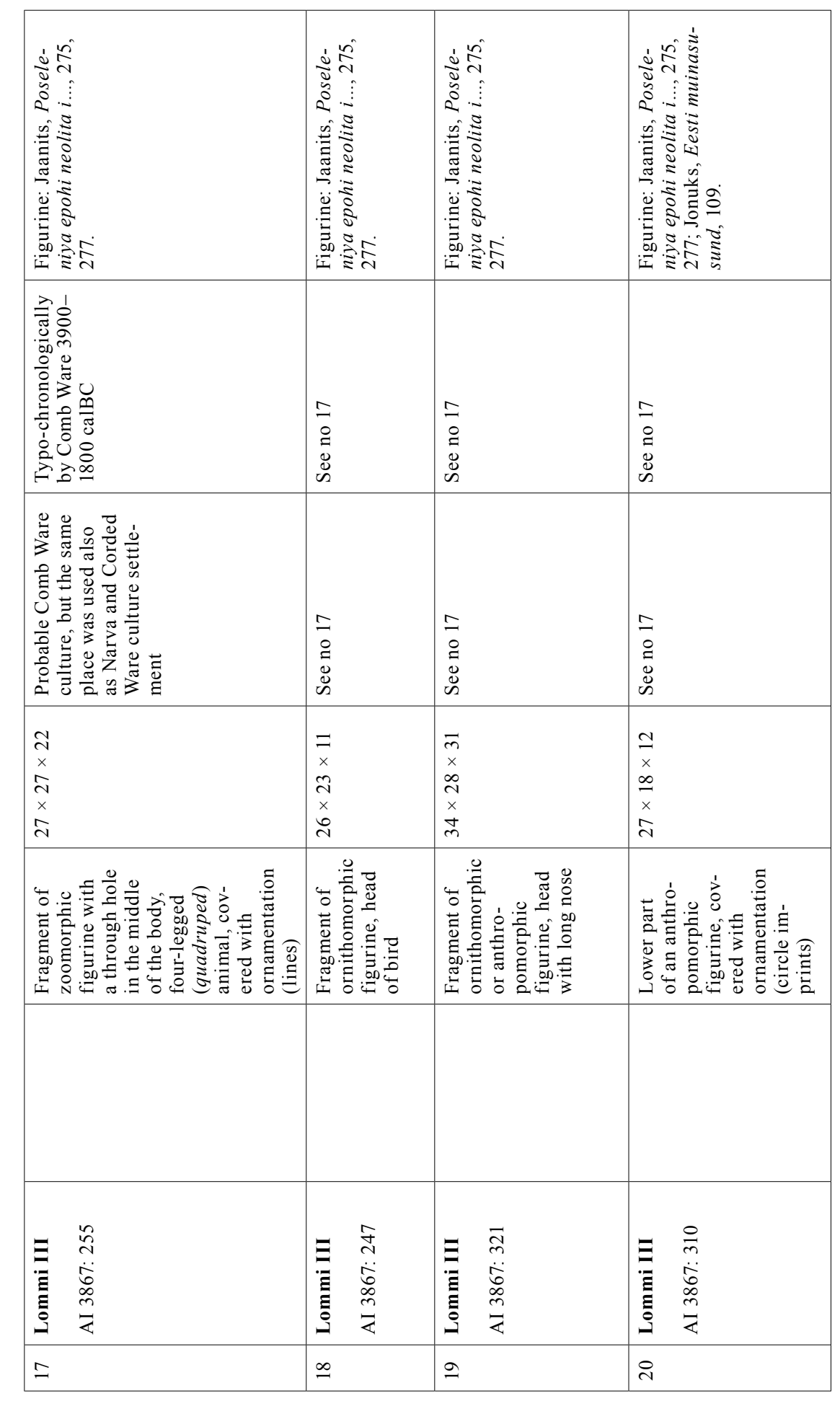




\begin{tabular}{|c|c|c|c|c|}
\hline 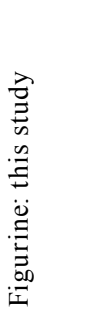 & 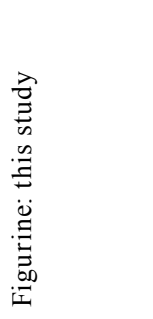 & 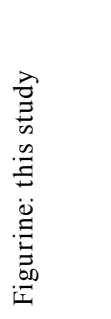 & 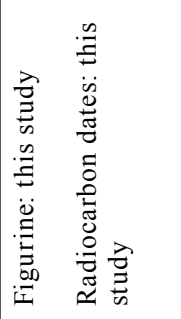 & \\
\hline 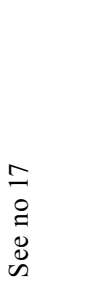 & 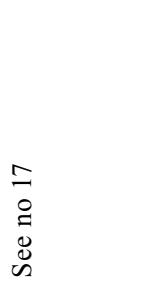 & 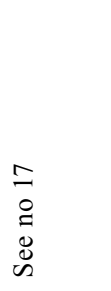 & 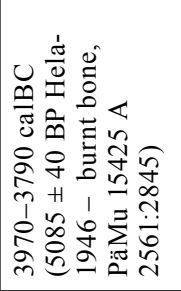 & 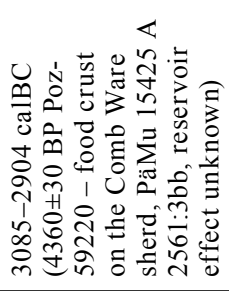 \\
\hline 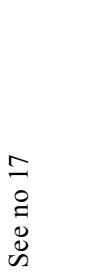 & 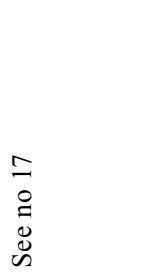 & 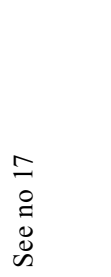 & 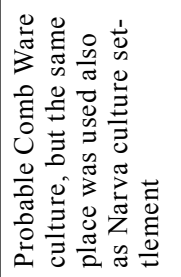 & \\
\hline $\begin{array}{l}= \\
x \\
n \\
n \\
x \\
\infty\end{array}$ & $\begin{array}{l}0 \\
\stackrel{0}{x} \\
\underline{1} \\
x \\
\stackrel{4}{1}\end{array}$ & $\begin{array}{l}\infty \\
0 \\
x \\
= \\
= \\
x \\
\stackrel{n}{1}\end{array}$ & 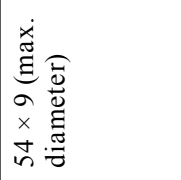 & \\
\hline 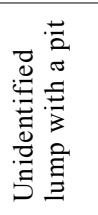 & 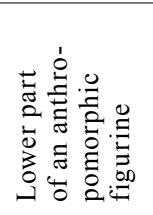 & 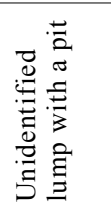 & 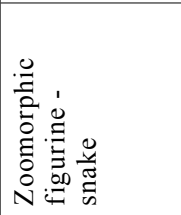 & \\
\hline 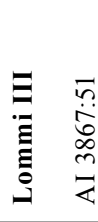 & 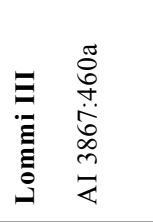 & 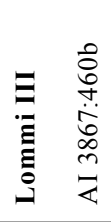 & 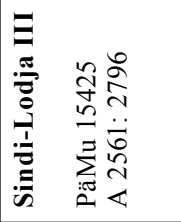 & \\
\hline$\vec{\sim}$ & $\approx$ & 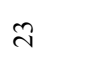 & $\underset{\sim}{\sim}$ & \\
\hline
\end{tabular}

\begin{tabular}{|c|c|c|c|c|}
\hline 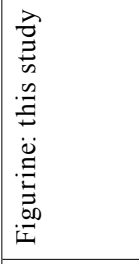 & 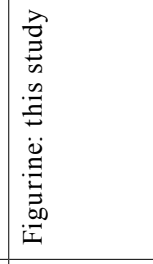 & 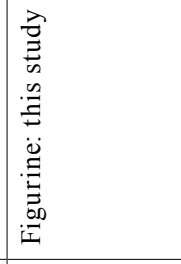 & 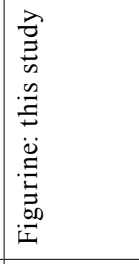 & 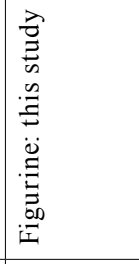 \\
\hline 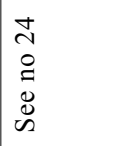 & 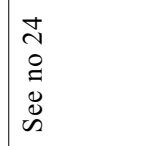 & 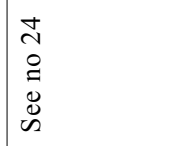 & 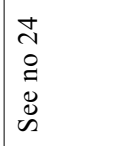 & 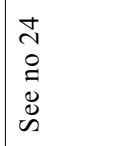 \\
\hline 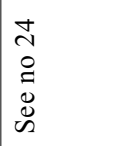 & 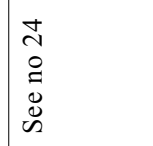 & 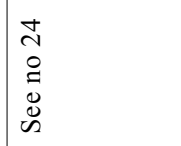 & 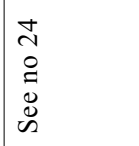 & 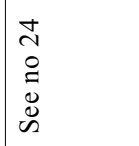 \\
\hline $\begin{array}{l}n \\
x \\
\infty \\
\infty \\
x \\
\vec{n}\end{array}$ & $\begin{array}{l}n \\
x \\
x \\
n \\
x \\
y \\
y\end{array}$ & $\begin{array}{l}r \\
x \\
\infty \\
\infty \\
x \\
0 \\
0\end{array}$ & $\begin{array}{l}a \\
x \\
= \\
x \\
a\end{array}$ & $\begin{array}{l}1 \\
\cdots \\
x \\
0 \\
x \\
x \\
\tilde{n}\end{array}$ \\
\hline 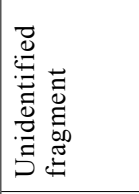 & 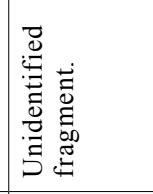 & 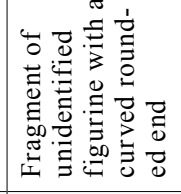 & 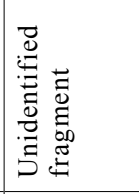 & 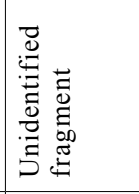 \\
\hline 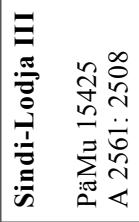 & 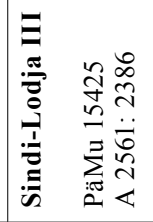 & 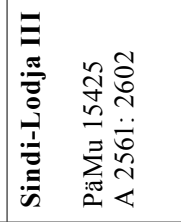 & 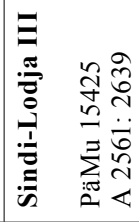 & 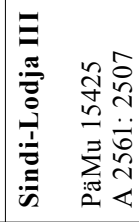 \\
\hline$\approx$ & $\stackrel{2}{2}$ & $\hat{\imath}$ & $\stackrel{\infty}{\sim}$ & ते \\
\hline
\end{tabular}




\begin{tabular}{|c|c|c|c|}
\hline 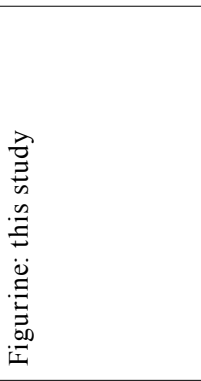 & 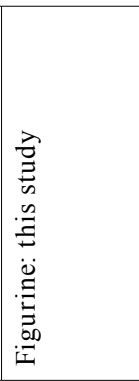 & 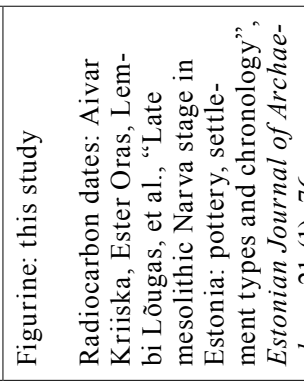 & \\
\hline 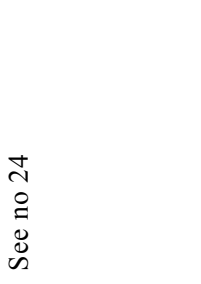 & 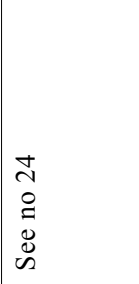 & 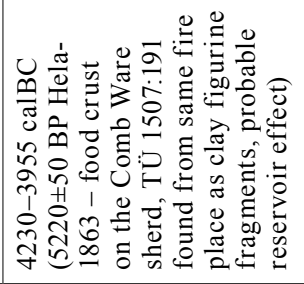 & 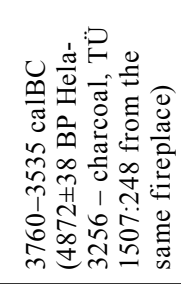 \\
\hline 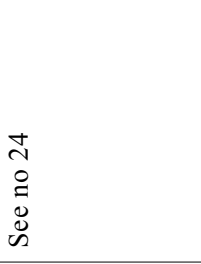 & 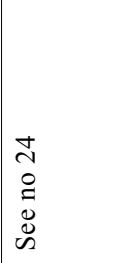 & 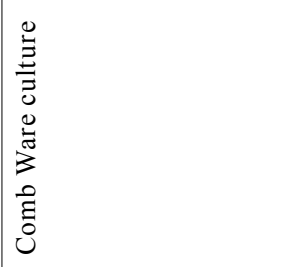 & \\
\hline $\begin{array}{l}m \\
x \\
x \\
\pm \\
x \\
n \\
n\end{array}$ & $\begin{array}{l}i \\
i \\
x \\
o \\
i \\
x \\
x \\
L \\
i\end{array}$ & $\begin{array}{l}m \\
x \\
x \\
0 \\
x \\
x \\
d \\
d\end{array}$ & \\
\hline 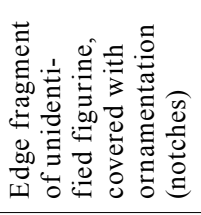 & 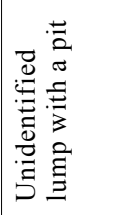 & 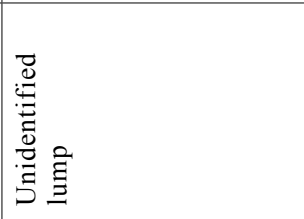 & \\
\hline 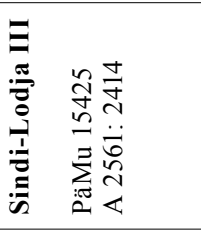 & 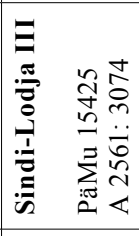 & 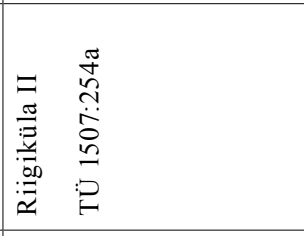 & \\
\hline ల & $\vec{m}$ & $\approx$ & \\
\hline
\end{tabular}

\begin{tabular}{|c|c|}
\hline 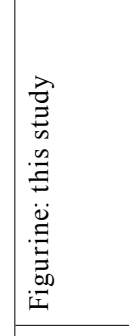 & 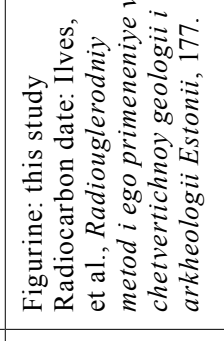 \\
\hline 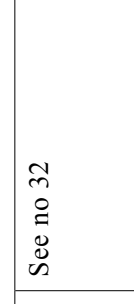 & 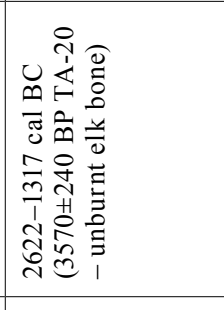 \\
\hline 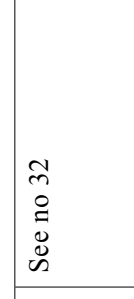 & 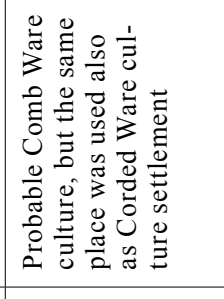 \\
\hline 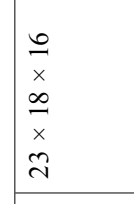 & \begin{tabular}{|l} 
\\
$y$ \\
$x$ \\
$x$ \\
$x$ \\
$d$ \\
$d$ \\
\end{tabular} \\
\hline 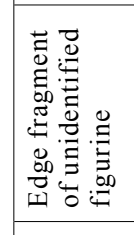 & 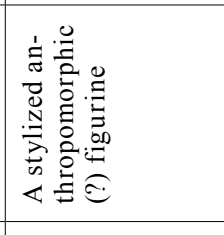 \\
\hline 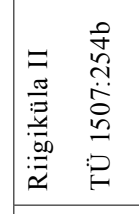 & 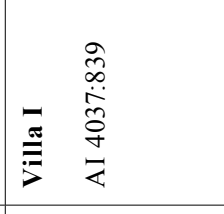 \\
\hline 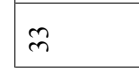 & 吕 \\
\hline
\end{tabular}


Irina Khrustaleva, Aivar Kritska: Inside the Dwelling: Clay Figurines of the Jägala Jõesuu V Stone Age Settlement Site (Estonia)

Keywords: Stone Age; Comb Ware culture; Estonia; Jägala; CLAY FIGURINES; INTENTIONAL BREAKAGE; DWELLINGS

\section{SUMMARY}

Sculpted clay figurines were widespread in Stone Age Europe. They were common in the hunter-gatherer communities in the territories of Sweden, Finland, Estonia, Latvia, Western and Northwestern Russia. In these territories they were mainly associated with the Comb, Pitted and Pit-Comb Ware cultures, ca 4000-2000 years calBC. This paper examines clay sculptures from the Jägala Jõesuu $\mathrm{V}$ Comb Ware culture settlement site in northern Estonia, where 91 fragments of figurines were found, making it the most abundant deposits of clay figurines and their fragments in the eastern Baltic. Among them, three different types of image were distinguished: one zoomorphic (harbour porpoise) and two anthropomorphic. All the figurines were fragmented intentionally in ancient times, as determined by microscopic and experimental research. Most of the fragments were situated in the filling of a pit-house, which indicates that the dwelling had a sacral as well as a habitational dimension. During the research process, Stone Age clay figurines from nine more Comb Ware culture sites of Estonia and Ingria were catalogued. The catalogue contains 13 previously published and 21 newly discovered instances and radiocarbon dates taken at the sites, some of which are being published for the first time.

\section{CV}

Aivar Kriiska (b. 1965) is Professor of Laboratory Archaeology at the University of Tartu (Estonia). His primary research interests are related to the Stone and Bronze Ages in Eastern and Northern Europe (early habitation of the forest zone in Europe, settlement and economic processes in Baltic coastal areas and islands, aDNA of Prehistoric populations, etc.), although he has also worked in other fields of archaeology, including Medieval and Modern Age town archaeology and experimental archaeology. He has published more than four hundred scientific and popular scientific articles and books.

Irina Khrustaleva (b. 1986) is a PhD student in the chair of Laboratory Archaeology at the University of Tartu (Estonia) and junior researcher at the Department of Archaeology of Eastern Europe and Siberia at the State Hermitage Museum (Russia). Her main research interests are related to the Stone Age of Eastern and Northern Europe (architecture, systems of organisation of prehistoric settlements, social and economic processes, flint and other stone raw materials) She has published more than thirty scientific and popular scientific articles and conference abstracts. 
